\title{
Milk Proteins-Their Biological Activities and Use in Cosmetics and Dermatology
}

\author{
Kinga Kazimierska and Urszula Kalinowska-Lis *(D) \\ Department of Cosmetic Raw Material Chemistry, Faculty of Pharmacy, Medical University of Lodz, \\ Muszyńskiego 1, 90-151 Łódź, Poland; kinga.kazimierska@stud.umed.lodz.pl \\ * Correspondence: urszula.kalinowska-lis@umed.lodz.pl; Tel.: +48-422725575
}

check for updates

Citation: Kazimierska, K.; Kalinowska-Lis, U. Milk

Proteins-Their Biological Activities and Use in Cosmetics and

Dermatology. Molecules 2021, 26, 3253. https://doi.org/10.3390/

molecules 26113253

Academic Editors: Maria

José Rodríguez-Lagunas and

Malen Massot-Cladera

Received: 17 April 2021

Accepted: 26 May 2021

Published: 28 May 2021

Publisher's Note: MDPI stays neutral with regard to jurisdictional claims in published maps and institutional affiliations.

Copyright: (c) 2021 by the authors. Licensee MDPI, Basel, Switzerland. This article is an open access article distributed under the terms and conditions of the Creative Commons Attribution (CC BY) license (https:// creativecommons.org/licenses/by/ $4.0 /)$.

\begin{abstract}
Milk and colostrum have high biological potential, and due to their natural origin and non-toxicity, they have many uses in cosmetics and dermatology. Research is ongoing on their potential application in other fields of medicine, but there are still few results; most of the published ones are included in this review. These natural products are especially rich in proteins, such as casein, $\beta$-lactoglobulin, $\alpha$-lactalbumin, lactoferrin, immunoglobulins, lactoperoxidase, lysozyme, and growth factors, and possess various antibacterial, antifungal, antiviral, anticancer, antioxidant, immunomodulatory properties, etc. This review describes the physico-chemical properties of milk and colostrum proteins and the natural functions they perform in the body and compares their composition between animal species (cows, goats, and sheep). The milk- and colostrum-based products can be used in dietary supplementation and for performing immunomodulatory functions; they can enhance the effects of certain drugs and can have a lethal effect on pathogenic microorganisms. Milk products are widely used in the treatment of dermatological diseases for promoting the healing of chronic wounds, hastening tissue regeneration, and the treatment of acne vulgaris or plaque psoriasis. They are also increasingly regarded as active ingredients that can improve the condition of the skin by reducing the number of acne lesions and blackheads, regulating sebum secretion, ameliorating inflammatory changes as well as bestowing a range of moisturizing, protective, toning, smoothing, anti-irritation, whitening, soothing, and antiaging effects.
\end{abstract}

Keywords: milk; colostrum; casein; $\beta$-lactoglobulin; $\alpha$-lactalbumin; lactoferrin; growth factors; skin; regeneration; antimicrobial; cosmetics

\section{Introduction}

Although milk is known to be used as a raw material in the food industry, it is also widely used in the pharmaceutical and cosmetic industries due to its considerable biological potential. It has also been the subject of detailed analyses and discussions of its individual components and their properties [1,2].

Milk contains the nutrients required for the growth and development of the neonate. It contains a colloidal dispersion of specific proteins as micelles, fats organized in emulsified globules, as well as lactose, various minerals, and vitamins in solution [3].

The composition of milk varies between species. The largest differences can be found between the protein content of individual species. Sheep milk and sheep colostrum is distinguished by the highest total protein and fat content, being almost one and a half that of cow or goat milk and colostrum (Table 1).

The initial milk, or colostrum, is produced by the mammary glands during pregnancy and immediately after delivery for about five days [4-6]. Colostrum is yellow, has a slightly acidic $\mathrm{pH}$ of about 6.4, and a higher density than later milk. Due to its intended use, it has a much higher content of biologically active substances that affect the immune system of neonates. 
Table 1. Composition of bovine, goat, and sheep colostrum and milk (\%) [3,7-13].

\begin{tabular}{ccccccc}
\hline \multirow{2}{*}{ Component } & \multicolumn{3}{c}{ Colostrum } & \multicolumn{3}{c}{ Milk } \\
\cline { 2 - 7 } & Bovine & Goat & Sheep & Bovine & Goat & Sheep \\
\hline Lactose & 3.6 & $3.39-4.24^{\mathrm{a}}$ & 3.3 & 4.6 & 4.1 & $4.8 ; 4.9^{\mathrm{b}}$ \\
Minerals & 0.9 & $0.85-0.9^{\mathrm{a}}$ & 0.9 & 0.7 & 0.8 & $0.94 ; 1^{\mathrm{b}}$ \\
Proteins & 7.1 & $3.53-5.69^{\mathrm{a}}$ & 11.8 & 3.4 & 2.9 & 5.5 \\
Fats & 5.1 & $3.88-8.21^{\mathrm{a}}$ & 13 & 3.7 & 4.5 & $6 ; 7.4^{\mathrm{b}}$ \\
\hline
\end{tabular}

${ }^{a}$ the minimum and maximum values from the test are given; ${ }^{b}$ given values from two sources.

Bovine colostrum is several times richer in caseins, $\beta$-lactoglobulins, $\alpha$-lactalbumin, immunoglobulins, GMP (glycomacropeptide) lactoferrin, and growth factors than milk. For example, the immunoglobulins content ranges from 20 to $150 \mathrm{~g} / \mathrm{L}$ in colostrum, but in the milk, only from 0.5 to $1.0 \mathrm{~g} / \mathrm{L}$. Only the content of lactoperoxidase and lysozyme remains at a similar level to both raw materials. Of all the types of colostrum presented, goat colostrum is the richest source of $\beta$-lactoglobulin. In goat colostrum, as in sheep colostrum, the content of $\beta$-lactoglobulin, $\alpha$-lactalbumin, $\operatorname{IgG}, \operatorname{IgM}, \operatorname{Ig} A$, and lactoferrin is much higher than in milk of the same species. Sheep milk is rich in casein in comparison to goat and bovine milk; its content, equal to $4.6 \mathrm{~g} / \mathrm{L}$, is almost twice as high as in goat's and cow's milk (2.5 g/L and 2.7-2.8 g/L, respectively) (Table 2). Therefore, colostrum from each of the mentioned species could be used as a raw material supplying proteins, especially those with biologically active properties.

The main source of active molecules of milk consists of casein and whey proteins, which demonstrate a range of antimicrobial, antioxidant, and immunomodulatory properties, among others [14]. Most biologically active proteins need to undergo proteolysis to achieve their full properties $[15,16]$. Proteolysis naturally occurs in the digestive tract, but it can also be initiated by the enzymes naturally found in milk, as well as by coagulants or lactic acid bacteria, which are often used in the food industry [15].

\section{Bioactive Proteins of Milk}

\subsection{Casein}

It belongs to the family of milk proteins containing phosphorus (phosphoprotein) and sugar (glycoprotein) residues; it consists of about 20 protein components. Caseins precipitate from raw, skimmed milk at a temperature of $20^{\circ} \mathrm{C}$ at a $\mathrm{pH}$ of 4.6. The proteins of the four casein fractions $\left(\alpha_{\mathrm{S}^{-}}, \alpha_{\mathrm{S} 2^{-}}, \beta-\right.$, and $\mathrm{K}$-casein) account for $80 \%$ of the total protein content in bovine milk. While $95 \%$ of the casein content is naturally self-assembled into casein micelles, i.e., spherical colloidal particles, approximately $10 \%$ is present in the form of single molecules as soluble casein. These two states, viz. molecular and micellar casein, exist in equilibrium [17]. Caseins can form dual-binding models that exploit their amphiphilic nature; interactions exist between hydrophobic regions of the proteins, with calcium phosphate clusters being linked to phosphoseryl clusters [18].

\subsubsection{Biological Properties of Casein}

The phosphoproteins contained in casein regulate the calcium and phosphate metabolism in the body. Improvement in bone mineralization in experimental animals was observed in postmenopausal models [19]. In addition, casein proteins inhibit tooth decay by increasing the calcium phosphate content in the plaque [20] (Table 2). $\alpha$-Casein, $\beta$-casein, $\alpha$ s1-casein, $\alpha$ s2-casein and $k$-casein can transform into biologically active molecules. For example, $\alpha$-casein forms an opioid, casomorphine, and $\alpha$ - and $\beta$-caseins are precursors of immunopeptides. In Figure 1, the bioactive peptides that are released from casein and their properties are shown $[14,16,21]$. 

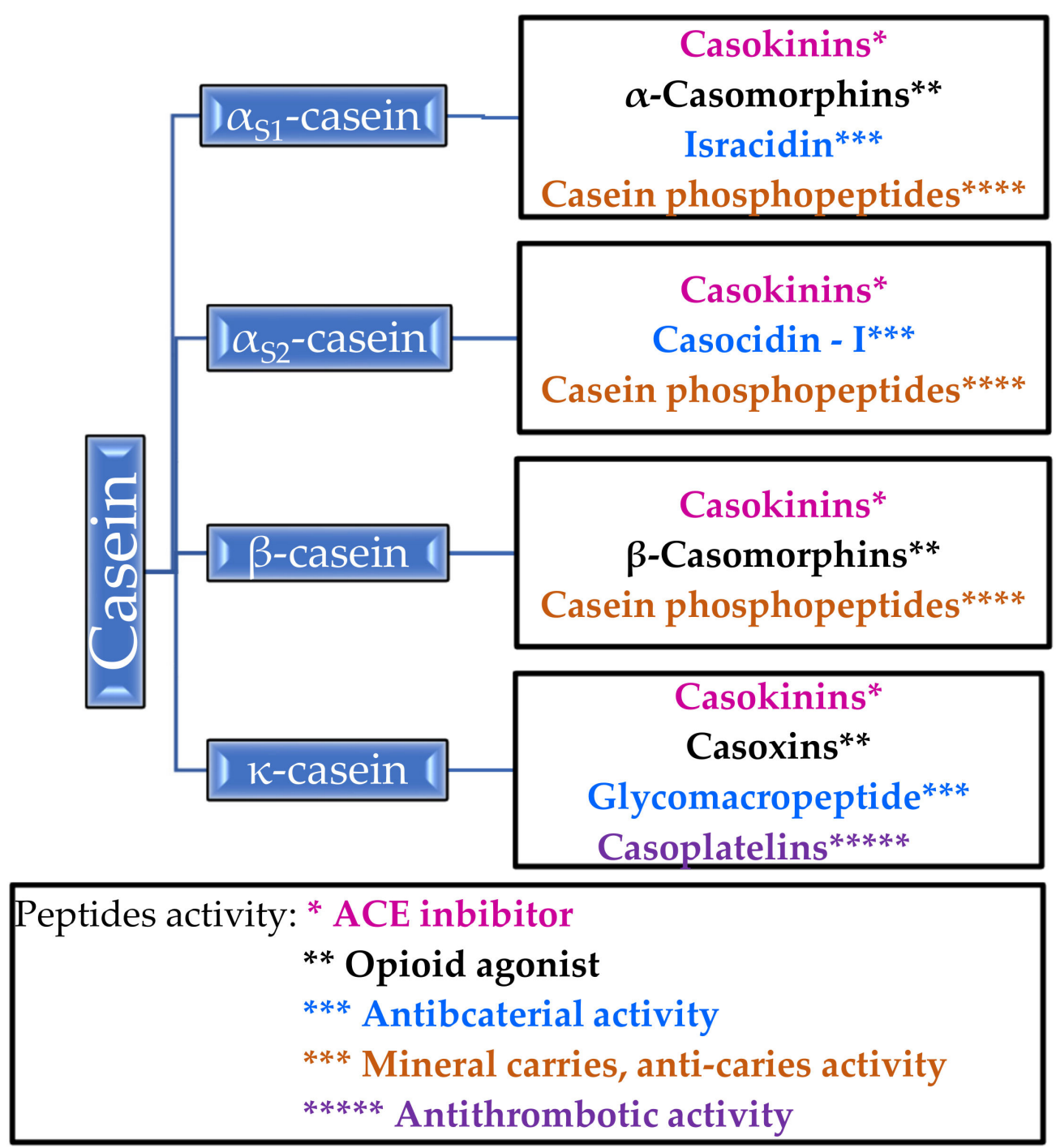

Figure 1. Peptides released from casein and their activity.

It is worth paying attention to casein phosphopeptides, which exhibit the properties of mineral carriers and anti-carriers-they form complexes with calcium ions and other mineral ions, thanks to which they increase the absorption of calcium in the intestines [14]. Unlike $\beta$-casomorphins, which are opioid agonists, casoxins are opioid antagonists [14,21]. Antithrombotic activity has been demonstrated for casoplatelins and antimicrobials in in vivo studies, especially against Streptococcus aureus, Streptococcus pyogenes, and Listeria monocytogenes [14]. Several of the listed peptides are described in more detail in Section 2.1.2. 
Table 2. Major bioactive protein components of bovine, goat, sheep colostrum, and milk.

\begin{tabular}{|c|c|c|c|c|c|c|c|}
\hline \multirow{2}{*}{ Proteins } & \multicolumn{3}{|c|}{ Colostrum } & \multicolumn{3}{|c|}{ Milk } & \multirow{2}{*}{ [Ref] } \\
\hline & Bovine & Goat & Sheep & Bovine & Goat & Sheep & \\
\hline Casein $(\mathrm{g} / \mathrm{L})$ & 2.6 & n.d. & n.d. & $* 2.7 ; 2.8$ & 2.5 & 4.6 & {$[14], *[22]$} \\
\hline $\mathrm{K}$-casein $(\%)$ & n.d. & n.d. & n.d. & * 12 & $* * 20.4$ & $* 9.1-10.2^{\mathrm{a}}$ & ${ }^{*}[23,24], * *[22]$ \\
\hline$\alpha \mathrm{S} 1$-casein $(\%)$ & n.d. & n.d. & n.d. & * 37 & $* * 5.6$ & *33.9-39.9 a & $*[23,24], * *[22]$ \\
\hline$\alpha \mathrm{S} 2$-casein $(\%)$ & n.d. & n.d. & n.d. & $* 10$ & ** 19.2 & ${ }^{*} 12-16.4^{\mathrm{a}}$ & $*[23,24], * *[22]$ \\
\hline$\beta$-casein $(\%)$ & n.d. & n.d. & n.d. & * 35 & $* * 54.8$ & $* 37-42.3^{\text {a }}$ & $*[23,24], * *[22]$ \\
\hline $\begin{array}{l}\beta \text {-lactoglobulin } \\
\quad(\mathrm{mg} / \mathrm{mL})\end{array}$ & * 7.9-30 & *9.3-49.8 & ** 4-19 & $* * * 3.3$ & $* * * * 3.07$ & $* * * * 5.97$ & $*[25],{ }^{* *}[26],,^{* * *}[14],{ }^{* * * *}[27]$ \\
\hline $\begin{array}{l}\alpha \text {-lactalbumin } \\
(\mathrm{mg} / \mathrm{mL})\end{array}$ & $* 3$ & $* * 2.77$ & $* * * 1.5-2$ & * 1.2 & $* * * * 1.27$ & $* * * * 0.95$ & ${ }^{*}[14],,^{* *}[25],{ }^{* * *}[26], * * * *[27]$ \\
\hline $\begin{array}{l}\text { Immunoglobulins } \\
(\mathrm{g} / \mathrm{L})\end{array}$ & $20-150$ & n.d. & n.d. & $0.5-1$ & n.d. & n.d. & [14] \\
\hline IgG & * 15-180 & $* * 50-60$ & $* * * 45-69$ & $* 0.35 ;{ }^{* *} 0.59 \mathrm{~b}$ & ** $0.1-0.4$ & $* * * * 0.35-1.62$ & ${ }^{*}[28-34],{ }^{* *}[22], * * *[35], * * * *[36]$ \\
\hline $\operatorname{IgM}$ & $* 4.2 ; * 5^{b}$ & * $1.6-5.2$ & $* * * 1.3-21.20$ & $* 0.05$ & * $0.01-0.04$ & $* * * 0.2$ & $*[13,37], * *[28-34], * * *[38]$ \\
\hline $\operatorname{IgA}$ & $* 3.5 ; * 3.9^{b}$ & $* * 0.9-2.4$ & $* * * 3.5$ & $* * 0.14$ & ** $0.03-0.08$ & $* * * 0.2$ & ${ }^{*}[28-34],,^{* *}[13,37], * * *[38]$ \\
\hline $\begin{array}{l}\text { Glycomacro-peptide } \\
(\mathrm{g} / \mathrm{L})\end{array}$ & 2.5 & n.d. & n.d. & 1.2 & n.d. & n.d. & {$[14]$} \\
\hline $\begin{array}{l}\text { Lactoperoxidase } \\
\text { (g/L) }\end{array}$ & ${ }^{*} 0.02 ;{ }^{* * *} 0.011-0.045^{b}$ & ${ }^{* *} 0.062-0.204$ & n.d. & ${ }^{*} 0.03 ;{ }^{* * *} 0.013-0.03^{b}$ & n.d. & n.d. & ${ }^{*}[14], * *[8], * * *[6]$ \\
\hline Lysozyme (mg/L) & * $0.14-0.7$ & n.d. & n.d. & ** $0.37-0.6$ & $* * 0.25$ & $* * 1-4$ & $*[44], * *[13]$ \\
\hline Serum albumin $(\mathrm{g} / \mathrm{L})$ & * 1.3 & n.d. & n.d. & *0.3 & $* * 0.26-0.3$ & ** $0.55-0.6$ & $*[14], * *[45]$ \\
\hline $\begin{array}{l}\text { Growth factors } \\
\qquad(\mu \mathrm{g} / \mathrm{L})\end{array}$ & $50 \mu \mathrm{g}-40 \mathrm{mg} / \mathrm{L}$ & n.d. & n.d. & $<1 \mu \mathrm{g}-2 \mathrm{mg} / \mathrm{L}$ & n.d. & n.d. & [14] \\
\hline IGF-I & ${ }^{*} 0.049-2{ }^{\mathrm{a}}$ & n.d. & $* * * 0.199-0.265 ; * * 50-500 \mathrm{~b}$ & ${ }^{*}<0.002-0.101$ & $* * * * 11-16.8^{a}$ & ** "low" & ${ }^{*}[46-58],{ }^{* *}[59],{ }^{* * *}[60], * * * *[61-63]$ \\
\hline IGF-II & $* * 0.15-0.6^{\mathrm{a}}$ & n.d. & n.d. & $* * 0.002-0.1^{\mathrm{a}}$ & $* 106$ & n.d. & $*[62], * *[46,51,56]$ \\
\hline EGF & $* 0.004-0.008 ; 0.3242^{b}$ & n.d. & $* * 1.7-2.3$ & $<0.002 ; 0.155^{\mathrm{b}}$ & n.d. & $* *<0.0008$ & $*[64,65], * *[66]$ \\
\hline TGF- $\beta 1$ & $0.0124-0.0426$ & n.d. & n.d. & $0.0008-0.0035$ & n.d. & n.d. & [49] \\
\hline TGF- $\beta 2$ & $0.15-1.15 ; 0.3^{b}$ & n.d. & n.d. & $0.013-0.07 ; 0.066^{b}$ & n.d. & n.d. & {$[48,67]$} \\
\hline
\end{tabular}

n.d.: no data; ${ }^{a}$ the minimum and maximum values from the test are given; ${ }^{b}$ found different values; ${ }^{*}, * *, * * *$ and ${ }^{* * * *}$ refer to the corresponding [Ref] in the last column. 


\subsubsection{Properties of Casein Peptides}

Casokinins are fragments of $\alpha$-casein and $\beta$-casein; these are believed to exhibit antihypertensive effects by acting as angiotensin-I converting enzyme (ACE) inhibitors [9]. Casokinins are mainly produced by the action of trypsin or chymotrypsin on $\beta$ - and $\alpha_{S 1-}$ casein [21]. ACE is an enzyme that catalyzes the conversion angiotensin I to the strong vasoconstrictor angiotensin II, thereby increasing blood pressure. Casokinins inhibit the action of ACE and thus lowers blood pressure in in vivo and in vitro studies [68-70].

Caseinomacropeptide (CMP) is split from casein by rennin during milk coagulation. It inhibits the aggregation of blood platelets and the binding of the human fibrinogen $\gamma$-chain to fibrinogen receptors on the platelet surface [14].

k-casein is a donor of glycomacropeptide (GMP) and can be obtained by the action of chymosin [9]. GMP has been found to inactivate microbial toxins of Escherichia coli and Vibrio cholerae, inhibit the adhesion of cariogenic Streptococcus mutans and Streptococcus sobrinus, and hemagglutination by four strains of influenza virus in in vitro tests. It also modulates immune system responses, promotes the growth of Bifidobacteria, suppresses gastric hormone activities, and regulates blood circulation through antihypertensive and antithrombotic activity [71,72].

GMP hydrolysate (GHP) has been found to increase the level of hepatic glycogen and ameliorate hepatic insulin resistance in high-fat diet (HFD)-fed mice, suggesting that GHP may improve the insulin sensitivity of insulin target organs [73]. GHP could reduce the levels of interleukin-6 (IL-6), interleukin-1 beta (IL-1 $\beta$ ), and tumor necrosis factor-alpha $(\mathrm{TNF}-\alpha)$ in macrophages [74].

GHP has been found to demonstrate effective hypoglycemic activity and to ameliorate dyslipidemia and inflammation in diabetic mice. GHP supplementation could influence the composition and diversity of gut microbiota, with potentially beneficial effects on the insulin signaling pathway and host metabolism. Hence, GHP may support the prevention and management of type 2 diabetes [75].

\subsubsection{Casein as Nanocarrier for Some Drugs}

As casein micelles act as carriers to provide newborns with nutrients such as calcium, phosphate, and protein, it has been proposed that they may be used to deliver vitamins, minerals, and antibacterial substances. Such drug delivery systems may improve the efficiency of drugs and avoid their toxic effects.

It has been shown that the micelles not only have an affinity for vitamin D2 but also protect it from light by absorbing its radiation on its surface, thus protecting drugs such as ergocalciferol from degradation [76].

In addition to its strong surface activity, particle stabilizing effect, and good adhesion strength, casein can form films; however, these films show poor flexibility and water resistance and are easily decomposed under the influence of bacteria, which limits their further use [77]. In order to improve the properties of casein, core-shell structural casein-based $\mathrm{ZnO}$ nanocomposites have been created by double in situ polymerization. The resulting nanocomposite film demonstrates improved thermal stability, lower water absorption rate, and excellent antibacterial properties against $E$. coli [77].

It has been found that $\beta$-casein also forms complexes with other biologically significant substances, protecting them and increasing their bioavailability. For example, binding resveratrol to $\beta$-casein in a casein micelle significantly improves its bioavailability. Both the existing cis- and trans-resveratrol isomers can be trapped in the micelle, and the betacasein-resveratrol complex has a much better protective effect during storage than $\beta$-casein micelles [78].

A particularly interesting and innovative example of the use of casein as a carrier is the creation of a complex with platinum. The clinical application of platinum-based anticancer drugs is greatly limited by their severe toxicity; however, a platinum(II) complex of bipyridine morpholine dithiocarbamate with nanoparticles composed of $\beta$-casein and chitosan demonstrated improved cytotoxicity and cellular uptake against colorectal cancer 
HCT116 cells, suggesting that this novel drug delivery system could enable the drugs to function in stable aqueous solutions and to be of use in targeted oral delivery applications. The nanoparticles demonstrated good colloidal stability and low cytotoxicity [79].

\section{2. $\alpha$-Lactalbumin}

$\alpha$-Lactalbumin is a hydrophilic albumin and globular protein. A single peptide chain consists of 123 amino acids. It accounts for about $20 \%$ of bovine whey proteins [80]. This albumin is a coenzyme in lactose biosynthesis and has the function of transporting calcium metal ions [44].

Biological Properties of $\alpha$-Lactalbumin

$\alpha$-Lactalbumin is a good source of opioid peptides. It has the ability to reduce stress and depressive moods by increasing brain tryptophan and serotonin levels [81-83].

Native $\alpha$-lactalbumin does not show antibacterial activity, unlike peptides isolated from $\alpha$-lactalbumin: LDT1 (1-5), LDT2 (17-31) S-S (109-114), LDC (61-68), and S-S (75-80). The first two peptides are formed under the influence of trypsin, and the third by chymotrypsin [84]. They have been found to be active mostly against Staphylococcus epidermidis ATCC 12228, Staphylococcus lentus, and Bacillus subtilis BGA [84].

The HAMLET/BAMLET (human $\alpha$-lactalbumin made lethal to tumor cells/bovine $\alpha$-lactalbumin made lethal to tumor cells) complex with oleic acid can penetrate tumor and immature cells, interfering with mitochondria, nucleosomes, and proteosomes, and activating apoptotic cancer cell pathways $[85,86]$. It has been reported to have comparable cytotoxic activity against lung cancer, kidney, and bladder carcinoma cell lines $[44,87,88]$. These findings suggest that such cytotoxic aggregates of apo-alpha-lactalbumin could be potential antitumor drugs.

\section{3. $\beta$-Lactoglobulin}

$\beta$-Lactoglobulin belongs to whey proteins and constitutes about $50 \%$ of these proteins [89]. Its content in colostrum is much higher than in milk and amounts to $7.9-30 \mathrm{mg} / \mathrm{mL}$ [6]. Structurally, it is a globular protein containing five cysteine residues, four of which are involved in the formation of disulfide bridges stabilizing the quaternary structure [44]. $\beta$-Lg is a rich source of calcium ion binding peptides [90].

Regarding its thermal stability, a temperature of $72{ }^{\circ} \mathrm{C}$ did not cause significant changes in the structure of the $\beta$-Lactoglobulin molecule in mixtures of other substances derived from milk; however, heating for $30 \mathrm{~s}$ at $100{ }^{\circ} \mathrm{C}$ resulted in significant changes, i.e., partial denaturation of particles [91]. This globulin is a carrier of retinol and fatty acids and is known to bind vitamin D and stimulate lipase activity [40-42]. In addition, when heated to $70-80{ }^{\circ} \mathrm{C}$, it loses the ability to actively bind palmitic acid, vitamin $\mathrm{D}$, and retinol [92].

\section{Biological Properties of $\beta$-Lactoglobulin}

Hernandez-Ledesma et al. isolated several antioxidant peptides by hydrolysis with Corolase PP. Their antioxidant activity was slightly higher than that of butylated hydroxyanisole (BHA) [93].

The $\beta$-Lg molecule also demonstrates significant antioxidant activity in milk, which, among others, has been attributed to the presence of sulfur-containing amino acids such as methionine [89-91]. These amino acids are also believed to exert antitumor effects [94]. Their activity is believed to be associated with the fact that methionine is a precursor of cysteine, which is needed for the formation of glutathione (GSH): a thiol antioxidant that scavenges reactive oxygen species, resulting in the formation of oxidized glutathione. Decreased amounts of GSH and a decreased GSH/GSSG ratio in tissues are biomarkers of oxidative stress. Chronic oxidative stress may lead to chronic inflammation and cancer development and progression [95].

The protein demonstrates antimicrobial effects by inhibiting the adhesion of pathogens to surfaces and thus preventing their colonization $[80,96]$. Bactericidal activity has been 
shown against both Gram-positive bacteria, such as B. subtilis and S. aureus, and Gramnegative ones, such as E. coli and Bordetella bronchiseptica [80]. Other studies also indicate that $\beta$-Lg chemically modified with 3-hydroxyphthalic anhydride, may be effective in inhibiting Chlamydia trachomatis infection; in addition, 3-HP- $\beta$-lactoglobulin is active against herpes simplex virus HSV-1 and -2 [97].

\subsection{Lactoferrin}

One of the bioactive whey proteins is Lactoferrin (LF). It was first isolated in 1939 from cow milk and later from human milk in 1960 [98]. It demonstrates a similar ironbinding capacity to transferrin proteins [44]. Lactoferrin is a monomeric glycoprotein; its polypeptide chain consists of two spherical lobes connected by a hinge region [99].

It is resistant to high temperatures and proteolytic enzymes [100]. LF can be found in saliva, bile, pancreatic fluid, amniotic fluid, and tears, but the highest concentration is found in human or porcine milk [44]. It is a component of neutrophils, from which it is released into the bloodstream during trauma, infection, and inflammation [101-103].

In milk, LF is mainly synthesized by glandular epithelial cells [103]. Its concentration ranges from 20 to $200 \mathrm{mg} / \mathrm{L}$ in cow milk, $140 \mathrm{mg} / \mathrm{L}$ in sheep milk, and 98-150 mg/L in goat milk $[13,39,40]$. Higher levels are found in the colostrum than in milk; for example, the level is around $0.8 \mathrm{~g} / \mathrm{L}$ in cow colostrum [41].

\subsubsection{Biological Properties of Lactoferrin}

Lactoferrin is a protein that is found in many body fluids such as colostrum, milk, tears, nasal secretions, saliva, and genital secretions. It is also produced in large quantities in neutrophils [42]. Lactoferrin demonstrates bactericidal, bacteriostatic, antiviral, antifungal, antiparasitic, anticancer and antioxidant properties [41,100,104-114]. In addition, several clinical studies have confirmed that bovine lactoferrin is an immune modulator that stimulates the phagocytic activity of multinucleated leukocytes [107] and reduces the production of interleukin (IL)- 6 and tumor necrosis factor (TNF)- $\alpha$ in cell cultures [106]. The mechanisms of action of lactoferrin related to individual types of its activity were presented in Table 3.

Table 3. Mechanisms of lactoferrin action.

\begin{tabular}{|c|c|c|}
\hline Kind of Activity & Mechanism of Action & [Ref.] \\
\hline \multirow[t]{2}{*}{ Antibacterial } & $\begin{array}{l}\text { - Reducing the concentration of iron ions that are } \\
\text { necessary to bacterial growth and proliferation } \\
\text { (chelation of iron via LF) } \\
\text { - Interacting with lipoteichoic acid (LTA) of the cell } \\
\text { walls of G(+) bacteria, disintegrating them and } \\
\text { increasing their permeability }\end{array}$ & {$[102,115,116]$} \\
\hline & $\begin{array}{l}\text { - Binding to lipopolysaccharide (LPS) of the walls of } \\
\mathrm{G}(-) \text { bacteria and disintegrating them. }\end{array}$ & \\
\hline \multirow{3}{*}{ Antifungal } & $\begin{array}{l}\text { - Damaging cell membranes of fungi and altering } \\
\text { their permeability }\end{array}$ & \multirow{3}{*}{ [117-119] } \\
\hline & - Sequestration of iron & \\
\hline & - Membrane destabilization & \\
\hline Antiviral & $\begin{array}{l}\text { - Blocking the host's cell surface receptors due to the } \\
\text { LF's affinity for glycosaminoglycans- Direct } \\
\text { interacting with capsid or viral envelope proteins }\end{array}$ & {$[113,120,121]$} \\
\hline
\end{tabular}


Table 3. Cont.

\begin{tabular}{|c|c|c|}
\hline Kind of Activity & Mechanism of Action & [Ref.] \\
\hline \multirow[t]{3}{*}{ Antiparasitic } & - Targets the host cell entry & [122-126] \\
\hline & $\begin{array}{l}\text { - Sequestration of iron- Probably linked to } \\
\text { sequestration of iron }\end{array}$ & \\
\hline & $\begin{array}{l}\text { - Acts additively or synergistically with the } \\
\text { antiparasitic compounds used in therapy }\end{array}$ & \\
\hline Antioxidant & $\begin{array}{l}\text { - Inhibiting the propagation of hydroxyl radicals by } \\
\text { sequestering cationic iron and copper }\end{array}$ & {$[109,115,127]$} \\
\hline Anticancer & $\begin{array}{l}\text { - Reducing the production of tumor necrosis factor } \\
\text { (TNF)- } \alpha \text { in cell cultures }\end{array}$ & [104] \\
\hline \multirow{5}{*}{ Immunomodulatory } & $\begin{array}{l}\text { - Stimulating the phagocytic activity of } \\
\text { multinucleated leukocytes }\end{array}$ & \multirow{5}{*}[98,103,104]{} \\
\hline & $\begin{array}{l}\text { - Reducing the production of interleukin (IL) -6 in } \\
\text { cell cultures }\end{array}$ & \\
\hline & - T-cell maturation & \\
\hline & - Stimulation of NK (natural killer cells) cells & \\
\hline & - Reducing pro-inflammatory cytokines & \\
\hline
\end{tabular}

The protein exerts antibacterial activity by chelating iron and removing it from the microbial growth environment [128]. It is also involved in the direct destruction of the sheaths and disruption of bacterial cell metabolism by inhibiting adhesion to host tissues [129], inhibition of biofilm formation by some bacteria [130], and stimulating the immune system to fight pathogens [112].

It has been proven to have a protective effect on intestinal epithelial cells and on the growth of beneficial intestinal microflora while inhibiting the growth of pathogenic bacteria such as E. coli, and especially those of the Enterobacteriaceae family [108].

It should be mentioned that the glycoprotein increases the sensitivity of bacteria to certain antibiotics such as vancomycin or penicillin, which reduces the supply of effective doses of individual drugs [131]. Diarra et al. showed that a mixture of lactoferrin and penicillin doubled the inhibitory activity against $S$. aureus [131].

Van der Kraan et al. isolated and characterized a new peptide, lactoferrampin, which, together with lactoferricin, a peptide derived from the hydrolysis of lactoferrin, showed antimicrobial properties against E. coli, L. amonocytogenes, B. subtilis, Pseudomonas aureoginosa, and Candida albicans [110].

Many clinical studies have found lactoferrin to have antiviral properties. It effectively inhibits the development of infection caused by hepatitis B and C [132], type I and II herpes simplex virus [128,133], HIV [134], human cytomegalovirus, HPV virus, enterovirus, influenza virus, and parainfluenza virus, and rotavirus [109,111,127,135].

The protein also prevents the formation of free radicals regulating the production and release of cytokines and tumor necrosis factor (TNF) [101]. Lactoferrin can serve as an antioxidant by sequestering cationic iron and copper and thereby inhibiting the propagation of hydroxyl radicals [136]. Lactoferrin has potential antioxidant properties due to the ability to sequester free iron ions [137].

\subsection{Lactoperoxidase (LPO)}

LPO is a glycoprotein that occurs naturally in milk, colostrum, and many other secretions [14]. It catalyzes the oxidation reaction of thiocyanates in the presence of hydrogen peroxide, thereby generating intermediates with a broad spectrum of antimicrobial activity [138-140]. Lactoperoxidase acts as a natural antibacterial agent as an element of non-specific cellular immunity $[100,141]$. Its concentration is $13-30 \mathrm{mg} / \mathrm{L}$ in cow colostrum and $11-45 \mathrm{mg} / \mathrm{L}$ in milk [6]. In vitro studies showed that LPO has bactericidal activity 
against Gram-negative bacteria such as E. coli, Salmonella spp., Pseudomonas spp., Campulobacter spp., and bacteriostatic properties against Gram-positive ones such as Listeria spp., Staphylococcus spp., Streptococcus spp. It has also demonstrated activity against Candida spp. and the protozoan Plasmodium falcipari, and has been found to inactivate HIV type 1 and poliovirus [142-146].

\subsection{Immunoglobulins}

They are high molecular globulins that can be divided into five classes, i.e., IgG, IgA, $\operatorname{IgM}, \mathrm{IgE}$, and $\mathrm{IgD}$. Each class has a similar structure composed of four polypeptide subunits [147]. In bovine milk and colostrum, the primary immunoglobulins are IgG, whereas in human milk, $90 \%$ of all immunoglobulins are sIgA; therefore, there are differences in the specifics of the action of total immunoglobulins [148]. The protective effects of immunoglobulins are presented below, as exemplified by Igs from bovine milk and colostrum. It is believed that the Igs in milk transport immunity from the mother to the neonate [44]. By binding antigens and stimulating phagocytosis or activating the complement system, immunoglobulins prevent pathogen adhesion, inhibit bacterial metabolism, and also neutralize toxins. Immunoglobulins thus participate in the destruction of pathogenic microorganisms such as E. coli, C. albicans, Clostridium difficile, Shigella flexneri, S. mutans, Helicobacter pylori, and Cryptosporiadium pravum [149,150].

The physical properties of Igs have a key influence on their natural antimicrobial properties and the possibilities of their further use. Igs are thermolabile, especially at high temperatures. Heating milk at $100{ }^{\circ} \mathrm{C}$ for $30 \mathrm{~s}$ damages the structure of Ig proteins, while heating at $72{ }^{\circ} \mathrm{C}$ for $15 \mathrm{~s}$ allows for mild pasteurization and maintains their active properties with no structural changes [91]. Therefore, extensive use of immunoglobulins is possible.

\subsection{Lysozyme}

Lysozyme is a hydrolase found at high concentrations in tears and chicken egg whites, from which it is obtained on an industrial scale, mainly by direct crystallization. Other methods for its preparation, like sequential dilution diafiltration using a UF membrane, affinity chromatography, adsorption, or molecular imprinted particles (Lys-MIP), are also known but used only in laboratory practice due to high costs [151,152]. Lysozyme stimulates the non-specific humoral immune response $[141,153]$. Its content has been found to vary from $0.37-0.6 \mathrm{mg} / \mathrm{L}$ in cow milk, $0.25 \mathrm{mg} / \mathrm{L}$ in goat milk, to $1-4 \mathrm{mg} / \mathrm{L}$ in sheep milk [13], and to range from $0.07-0.6 \mathrm{mg} / \mathrm{L}$ cow milk and $0.14-0.7 \mathrm{mg} / \mathrm{L}$ in colostrum [44].

Lysozyme exerts its antimicrobial activity by catalyzing the hydrolysis of the $\beta-1,4$ bonds in peptidoglycan, a component of bacterial cell walls; it is active against Grampositive bacteria and demonstrates synergistic bactericidal activity with lactoferrin against S. epidermis [44]. Lysozyme is also called an endogenous antibiotic due to its supportive effect on bactericidal and bacteriostatic drugs [105]. The formation of a complex of lysozyme with oleic acid shows promising bactericidal effects against Streptococcus pneumoniae [154], and the lysozyme- $\mathrm{ZnO}$ nanoparticles complex demonstrates synergistic activity against E. coli and S. aureus [155]. Lysozyme applications in the industry could expand with the increased production of lysozyme afforded by the use of transgenic animals, whose milk contains levels as high as $25 \mathrm{mg} / \mathrm{L}$ [44].

\subsection{PRP (Proline-Rich Peptide)}

It is a complex composed of a mixture of 32 peptides of various molecular masses ranging from $500-3000 \mathrm{kDa}$. This group of similar molecules demonstrates a broad spectrum of regulatory activity supporting the development of the immune system, inducing the maturation and differentiation of murine thymocytes, and affecting humoral and cellular immune responses. PRP consists of proline residues (25\%) and hydrophobic amino acids $(40 \%)$ [156]. It possesses homology to three protein precursors: annexin, $\beta$-casein, and a hypothetical $\beta$-casein homolog [157]. 
PRP was first isolated from ovine colostrum and was subsequently found in human and cow colostrum [156]. PRP exhibits immunomodulatory properties, inducing maturation and differentiation of thymocytes, the proliferation of pheochromocytoma cells increases the viability of fibroblast cells and inhibits $\beta$-amyloid-induced apoptosis [158]. It has been found to influence precognitive functions in animal models, and hence to exert a potential influence on central nervous system processes. Clinical studies on the effects of sheep colostrum PRP administration in patients with Alzheimer's disease (trade name Colostrinin Tm; ReGen Therapeutics Ltd., London, UK) found it to have a beneficial effect on disease symptoms and everyday functioning in $\mathrm{AD}$ patients and a negligible number of very mild side effects [159].

\subsection{Growth Factors}

Growth factors, which are generally considered a subset of cytokines, are signaling proteins that stimulate cell growth, differentiation, survival, inflammation, and tissue repair. They can be secreted by neighboring cells, tissues and glands, and even cancer cells. All cells need a range of growth factors to maintain proliferation and viability [160-162]. The first information about the presence of growth factors in milk and colostrum was recorded in 1997 by Pakkanen and Aalto and later by Gauther et al. in 2006 [141,163]. The following growth factors are known to be present in milk: BTC (Betacellulin GF), EGF (Epidermal GF), FGF-1, FGF-2 (Fibroblast GF), IGF-1 and IGF-2 (Insulin-like GF), TGF- $\beta 1$, TGF- $\beta 2$ (Transforming GF), and PDGF (Platelet-derived GF) [101]. Of these, the most prevalent are epidermal (EGF), insulin-dependent (IGF), and transformative (TGF) growth factors [141], with concentrations of 2-155 ng/mL for EGF, 2-101 ng/mL for IGF-I, $2-107 \mathrm{ng} / \mathrm{mL}$ for IGF-II and $13-71 \mathrm{ng} / \mathrm{mL}$ for TGF- $\beta 2$, and $<4 \mathrm{ng} / \mathrm{mL}$ for BTC, TGF- $\beta 1$, FGF1, and FGF2 [163].

Growth factors demonstrate a multilevel effect on individual cells and tissues. EGF and BTC stimulate the proliferation of epidermis, epithelium, and embryonic cells, and promote wound healing, bone reconstruction and inhibit gastric secretion [163]. TGF- $\beta$ is responsible for embryo development and repair and the formation of bone, cartilage, and epithelial tissue; it also regulates the immune system [163]. Some supplements have been designed with the aim of increasing immunity and treating conditions such as childhood Crohn's disease, e.g., Nestle Modulen IBD containing TGF- $\beta 2$ from milk [164-166]. IGF, which includes IGF-I and IGF-II, stimulates the proliferation of many cells and also regulates metabolic functions, e.g., glucose uptake or glycogen synthesis [163]. Due to their wide range of action, these growth factors have been included in studies on treating epilepsy [167]. Playford et al. [168] suggest that cow colostrum-based products that contain growth factors can be used to counteract side effects when using nonsteroidal anti-inflammatory drugs. Gauthier et al. [163] described a positive effect of growth factors on the digestive system, skeletal system, and skin.

Particularly important in the context of this article seems to be the study, the results of which indicate that FGF, IGF-1, and EGF are important mitogens in wound healing and that EGF, in particular, is capable of stimulating the epithelium. IGF-1 and EGF may play a significant role in both the early and late wound environment, while FGF may play the most important role in early tissue repair [169].

\section{Milk- and Colostrum-Based Products in Cosmetics and Dermatology}

Recent years have seen a growth in interest in natural products, and milk- and colostrum-based products are now widely used in the cosmetics and pharmaceutical industries. In this chapter, their impact on skin conditions when used as a dietary supplement or topically applied in the form of creams, ointments, etc., will be discussed. These data are summarized in Table 4. This section will also present the effect of milk or milk-derived ingredients on skin cells (fibroblasts and/or keratinocytes) in vitro. 


\subsection{Impact of Supplementation with Milk- and Colostrum-Based Products on Skin Conditions}

Substances derived from colostrum and milk, especially proteins, have been shown to have great therapeutic potential in the treatment and prevention of many diseases, and there is a growing demand for those based on colostrum. A number of colostrumsupplemented powders, capsules, lozenges, beverages, and chewing gums are available on the market. The products are used not only as wound healing factors and antioxidants, anti-inflammation, tissue growth agents but also to enhance the immune system, repair damaged gastrointestinal tissues, or encourage the differentiation and proliferation of epidermal cells, among others [5,43].

The milk protein most commonly used as a supplement is lactoferrin, possibly due to its broad spectrum of proven biological properties (Section 2.4.1). This has been found to induce a significant improvement in the skin condition of patients with psoriasis and acne vulgaris, including a reduction in the number of inflammatory lesions and an overall improvement in the clinical picture [90,170-172].

One study compared the effect of consuming fermented milk enriched with lactoferrin (200 mg daily) by patients with acne vulgaris in the course of skin inflammation. Two groups of 18 patients, one consuming enriched milk and the other unenriched milk (placebo), were tested for skin hydration, sebum, $\mathrm{pH}$, and skin surface lipid content at the beginning of the study and after 12 weeks. The group of patients taking lactoferrin-enriched milk demonstrated a 38.6\% improvement in inflammation reduction, 31.1\% lower sebum content, $23.1 \%$ fewer total lesions, and $20.3 \%$ lower acne severity compared to the placebo group. Although both groups displayed a decrease in lipid level on the skin surface, the lactoferrin-receiving group also demonstrated a decrease in the triacylglycerol content of the lipids; this was found to correlate with the reduction in acne lesions and the severity of acne. The hydration and $\mathrm{pH}$ of the skin reminded unchanged after supplementation [90].

Twice daily administration of lactoferrin $(100 \mathrm{mg})$ as a dietary supplement was found to result in an overall improvement in acne lesions in patients with mild to moderate common acne [170]. Twice daily administration of capsules containing lactoferrin with vitamin $\mathrm{E}$ and zinc for three months was found to reduce the number of acne lesions, reduce blackheads and inflammatory changes, and better regulate sebum secretion. The preparation was found to be both safe and effective [173].

In addition, an orally administered preparation based on milk proteins, rich in growth factors, alpha-lactalbumin, lactoferrin, and immunoglobulins in reducing skin lesions has been found safe for use in patients with plaque psoriasis [171].

Lactoferrin supplementation was also found to inhibit the increase in transepidermal water loss, reduction in skin hydration, aberrant epidermal hyperplasia, and cell apoptosis in hairless mice orally administered lactoferrin and exposed to UVB radiation [172].

The vitamins, minerals, and amino acids contained in colostrum are known to bestow many health-promoting effects on human skin. Ascorbic acid (vitamin C) is involved in the production of collagen and L-carnitine; it also maintains healthy skin, heals wounds, and possesses antioxidant activity. In addition, niacin (vitamin B3) maintains healthy skin, biotin (B7) strengthens hair and nails, vitamin E possesses antiaging and antioxidant activity, and retinol (vitamin A) encourages skin cell production and has antiaging properties. The various minerals present, such as zinc and copper, take part in neutralizing the harmful effects of free radicals, regeneration processes, and wound healing.

The amino acids also have positive effects: proline has antiaging properties (reduces wrinkles and sagging), forms collagen, and heals tissue, threonine produces collagen and elastin in the skin, methionine has an antioxidant effect, synthesizes collagen in nails and hair and arginine stimulates wound healing [43]. 
Table 4. Clinical studies with milk-or colostrum-based products.

\begin{tabular}{|c|c|c|c|}
\hline Product Used & $\begin{array}{l}\text { Type of Disease or Healthy Skin } \\
\text { (Number of Patients) }\end{array}$ & Result of the Study & [Ref.] \\
\hline \multicolumn{4}{|c|}{ Topically applied milk-based products } \\
\hline $\begin{array}{l}\text { bovine colostrum preparation } \\
\text { (supported antibiotic therapy) }\end{array}$ & $\begin{array}{l}\text { difficult-to-heal wounds caused by } \\
\text { buttock erythematosus and by erosion } \\
\text { erythema }\end{array}$ & significant improvement in wound healing & [174] \\
\hline $\begin{array}{l}\text { ointments containing } 10 \% \text { and } 20 \% \\
\text { lactoferrin }\end{array}$ & moderate psoriatic plaque $(n=22)$ & $\begin{array}{l}\text { improvement in elevation, redness, and } \\
\text { scaling of psoriatic lesions }\end{array}$ & [114] \\
\hline soap containing $5 \%$ Podolian cow milk & healthy skin & $\begin{array}{l}\text { good cleansing and antibacterial } \\
\text { properties }\end{array}$ & [175] \\
\hline $\begin{array}{l}\text { creams with skimmed donkey milk } \\
\text { encapsulated in nanoliposomes }\end{array}$ & healthy skin $(n=15)$ & $\begin{array}{l}\text { satisfactory moisturizing properties; } \\
\text { antiaging effects }\end{array}$ & [176] \\
\hline cream containing $30 \%$ horse colostrum & seborroic acne $(n=12)$ & complete skin regeneration & [177] \\
\hline $\begin{array}{l}\text { cream containing } 20 \% \text { horse colostrum } \\
\text { and } 10 \% \text { horse milk (plus mint and } \\
\text { benzocaine) }\end{array}$ & contact skin lesions $(n=5)$ & $\begin{array}{l}\text { resolution of contact skin lesions and pain } \\
\text { immediately after application }\end{array}$ & [177] \\
\hline $\begin{array}{l}\text { cream containing } 20 \% \text { horse colostrum } \\
\text { and } 10 \% \text { horse milk (plus mint and } \\
\text { benzocaine) }\end{array}$ & hyperthermia sunburn skin $(n=30)$ & $\begin{array}{l}\text { immediate relief of pain and skin tension } \\
\text { (within } 24 \text { h); the appearance of a normal } \\
\text { tan, without any scale-off skin effect }\end{array}$ & [177] \\
\hline $\begin{array}{l}\text { cream containing } 20 \% \text { horse colostrum } \\
\text { and } 10 \% \text { horse milk (plus mint and } \\
\text { benzocaine) }\end{array}$ & $2^{\circ}$ degree and $3^{\circ}$ fire burns $(n=8)$ & $\begin{array}{l}\text { rapid pain relief; rebuilding the } \\
\text { epithelium in a week }\end{array}$ & [177] \\
\hline emulsion with $20 \%$ horse colostrum & moderate atopic dermatitis $(n=7)$ & $\begin{array}{l}\text { reduction in erythema and pruritus; } \\
\text { softening, moisturizing, soothing, and } \\
\text { anti-inflammatory effects }\end{array}$ & [177] \\
\hline $\begin{array}{l}\text { liposomal gel containing } 20 \% \text { horse } \\
\text { colostrum }\end{array}$ & ulcerative skin lesions $(n=10)$ & improvement of skin healing and repair & [177] \\
\hline $\begin{array}{l}\text { cosmetic formulations based on a } \\
\text { combination of horse colostrum and } \\
\text { horse milk }\end{array}$ & healthy skin & $\begin{array}{l}\text { antiaging, moisturizing, protective, } \\
\text { tensio-distensive, tonic, smoothing, } \\
\text { anti-irritant, emollient, bleaching, } \\
\text { decongestant, and sebostatic effects }\end{array}$ & [177] \\
\hline $\begin{array}{l}\text { fermented (by lactic acid bacteria) horse } \\
\text { colostrum }\end{array}$ & atopic dermatitis (atopy and psoriasis) & $\begin{array}{c}\text { alleviating symptoms; } \\
\text { moisturizing and anti-inflammatory } \\
\text { effects }\end{array}$ & [178] \\
\hline fermented colostrum & acne & $\begin{array}{c}\text { improvement related to the antibacterial } \\
\text { effect }\end{array}$ & [179] \\
\hline $\begin{array}{l}\text { formulations containing bovine or } \\
\text { equine colostrum (plus hyaluronic acid } \\
\text { or its salt and olive oil or vitamin E) }\end{array}$ & healthy skin of elderly volunteers & $\begin{array}{l}\text { improvement elasticity and tension; } \\
\text { moisturizing and antioxidant effects; } \\
\text { reduction in skin sagging and liver spots }\end{array}$ & [180] \\
\hline $\begin{array}{l}\text { cosmetic formulation based on } \\
\text { colostrum albumin (plus arbutin) }\end{array}$ & healthy skin with discoloration & whitening properties & [181] \\
\hline \multicolumn{4}{|c|}{ Milk-based products used as supplements } \\
\hline $\begin{array}{l}\text { fermented milk enriched with } \\
\text { lactoferrin }\end{array}$ & acne vulgaris $(n=18)$ & $\begin{array}{l}\text { reduction in inflammation, sebum content, } \\
\text { and the severity of acne lesions }\end{array}$ & [90] \\
\hline lactoferrin & mild to moderate common acne & overall improvement in acne lesions & {$[170]$} \\
\hline $\begin{array}{l}\text { capsules containing lactoferrin (plus } \\
\text { vitamin E and zinc) }\end{array}$ & acne & $\begin{array}{l}\text { reduction in the number of acne lesions, } \\
\text { blackheads, and inflammatory changes; } \\
\text { regulation of sebum secretion }\end{array}$ & [173] \\
\hline
\end{tabular}

\subsection{Influence of Milk or Milk-Derived Ingredients on Skin Cells In Vitro}

Skim bovine colostrum has been found to increase canine skin fibroblast proliferation. Bovine colostrum stimulated fibroblast growth at all doses $(0.1,0.3$, and $1 \mathrm{mg} / \mathrm{mL})$ after $24 \mathrm{~h}$ incubation. Proliferation was found to increase from $19 \%$ to $32 \%$ compared to negative controls, and the effect remained significant after $48 \mathrm{~h}$ for the 0.3 and $1 \mathrm{mg} / \mathrm{mL}$ doses [182].

The fat fractions isolated from mare's colostrum were found to have a stronger effect on fibroblast proliferation in vitro than those from milk. The different lipid pattern of the 
two substances, specifically the higher levels of adipophilin and lactadherin in colostrum fat globules, is believed to have affected skin wound repair efficiency. Colostrum also contains higher levels of total lipids, linoleic and linolenic acids, gangliosides, and glycolipids when compared to milk $[5,183]$.

Colostrum has a positive effect on the healing process of skin wounds. This may be due to the participation of growth factors and/or other immune regulatory factors [5].

Peptides from milk protein hydrolysates, typically with a molecular weight of $800 \mathrm{Da}$ and containing mainly hydrophobic aromatic amino acids, have been found to promote growth in human skin cells in vitro. Treatment promoted growth efficacy by $108 \%$ in keratinocytes cultured in a medium supplemented with $300 \mu \mathrm{g} / \mathrm{mL}$ of one peptide fraction for 12 days [184].

Other studies have examined the effect of donkey colostrum and mature milk, human colostrum and mature milk, and $\beta$-casein and $\beta$-casomorphine- 7 on the growth and inflammatory response of the skin fibroblast culture. Exposure of skin fibroblasts to donkey milk and human colostrum resulted in a decrease in proinflammatory transcriptional factor NF-kB p65 activity. The opposite effect was noticed for $\beta$-casein and $\beta$-casomorphine-7. Moreover, it was proved that the tested products and $\beta$-casein lead to the activation of growth-regulating kinases (Akt 1/2/3 kinase, Erk kinase, INK kinase, and Stat-1 kinase), especially the p-Erk pathway. Accordingly, it can be concluded that casein amino acids may be responsible for the activation and proliferation of the cell cycle initiated by Erk. It suggests that noncasein bioactive peptides of donkey and human milk may be responsible for anti-inflammatory properties and may be useful in wound healing, regenerative, and aesthetic dermatology [185].

Recently, Kovacs et al. showed that colostrum promotes cell cycle withdrawal by increasing the expression of kinase inhibitors and promotes the transition of keratinocytes from proliferation to differentiation. Colostrum also has the ability to induce the expression of early and late differentiating markers (keratin 1, involucrin, and filaggrin) and the synthesis of caspase 14 and bleomycin hydrolase: two major enzymes involved in the maturation of filaggrin. Bovine colostrum has been found to promote keratinocyte section and final differentiation in two-dimensional (2D) and three-dimensional (3D) skin counterparts, the latter being a more physiologically representative system. Colostrum appears to stimulate cell differentiation via the PI3K/PLC- $\gamma 1 /$ PKC $\alpha$ (3-phosphatidylinositol kinase/phospholipase $C \gamma 2$ /protein kinase $C \alpha$ ) pathways associated mainly with tyrosine kinase receptors; this suggests that colostrum may be used in the treatment of skin diseases characterized by a perturbed barrier function, such as cutaneous dryness in elderly or UVR-exposed subjects [186].

\subsection{Topical Applications of Milk or Colostrum Containing Products}

The properties of milk proteins make them promising candidates researchers are trying to use them to create a skin substitute for the treatment of burn wounds. A preliminary study showed that the application of bioactive milk proteins, lactoferrin, and whey proteins on a synthetic polymer (polycaprolactone) scaffold increased the growth, spread, and infiltration of keratinocytes and fibroblasts. Hence, it could be effectively used to heal wounds [187].

Milk proteins have also been used directly on the skin for therapeutic purposes. Topical application of bovine colostrum preparations resulted in significant improvement in the treatment of difficult-to-heal wounds caused by buttock erythematosus and by erosion erythema when administered as support for systemic antibiotic therapy [174].

An ointment consisting of Gundelia (Gundelia tournefortii L.) extract with milk cream (GT/MC 4:1) was found to support the healing of second-degree burn in a rat model. Thirty-six male Wistar rats with second-degree burns on the skin were divided into three groups: one treated with silver sulfadiazine drug, another treated with G. tournefortii L. extract composite with milk cream, and one untreated group. Of the three, the GT/MC ointment group demonstrated the most effective healing. After 21 days of treatment, the 
wound area was reduced, and the wound healing process was improved significantly. Thus, such an ointment could aid in the healing of burn wounds [188].

Bovine lactoferrin may be considered as a topical treatment option for the treatment of psoriatic plaque. This is confirmed by studies conducted on a group of 22 patients with moderate plaque psoriasis who used ointments containing $10 \%$ and $20 \%$ lactoferrin. The psoriatic lesions treated with lactoferrin demonstrated improvements in elevation, redness, and scaling; however, the $20 \%$ ointment did not appear to be more effective than the $10 \%$ [114].

Podolian cow milk has also been used as a raw material for skincare products in the form of liquid hand soap. The product was found to demonstrate good cleansing and antibacterial properties. The most effective was the soap containing $5 \%$ of Podolian milk, which reduced bacterial hand contamination by $98 \%$. The antibacterial activity of the product derived from the presence of some milk protein, as well as various enzymes, such as lysozyme $(0.25 \mathrm{mg} / \mathrm{L})$, lactoferrin, and lactoperoxidase [175].

Another study compared the effects of creams with nanoliposomes encapsulated with skimmed donkey milk with placebo on untreated skin in fifteen healthy volunteers. Shortly after application, the creams demonstrated satisfactory moisturizing properties, which were maintained throughout the entire period. Transepidermal water loss slightly decreased only after four weeks, and the $\mathrm{pH}$ value was similar after each of the treatments. The creams may contribute to additional antiaging effects [176]. The formulations containing the skimmed donkey milk are described in detail in the Serbian patent (P-2016/0289; No 57752) [189].

Scientific publications regarding the external application of colostrum to the skin are sparse. However, many patents relating to colostrum-based dermocosmetics are pending.

In accordance with the patent US5750149A [177], formulations containing horse colostrum together with horse milk have been clinically tested. The studies investigated preparations with different ratios of colostrum to milk content, i.e., $30 \%$ horse colostrum, $20 \%$ horse colostrum and $10 \%$ horse milk, $10 \%$ horse colostrum and $20 \%$ horse milk, and $3 \%$ horse colostrum and $20 \%$ horse milk. When applied to the skin, the formulations were effective in the treatment of sunburns, burns from fire, contact lesions, skin diseases such as acne, seborrhea dermatitis, irritation, keratosis defects (psoriasis and ichthyosis), including atopic dermatitis and itching, among others [177].

In addition, twice-daily topical application of a cream containing $30 \%$ of horse colostrum led to resolution of cutaneous lesions in twelve patients aged 16-27, affected by seborrheic acne, with the skin being completely regenerated [177].

Twice-daily topical treatment, i.e., every $12 \mathrm{~h}$, with a cream containing $20 \%$ horse colostrum and $10 \%$ horse milk, with the addition of mint and benzocaine, resolved contact skin lesions within $24 \mathrm{~h}$ in five test subjects, with the pain disappearing immediately after application [177]. The same cream, based on $20 \%$ horse colostrum and $10 \%$ horse milk plus mint and benzocaine, was applied twice-daily in adult patients with hyperthermia sunburn skin; the same extract was also applied to children but with the addition of chamomile extract instead of peppermint. The study group consisted of thirty people. The results indicated that pain subsided immediately, skin tension dropped over the course of $24 \mathrm{~h}$, and a normal tan appeared, without any scale-off skin effect in the following days [178]. The cream was also found to be effective in the treatment of $2^{\circ}$ degree and $3^{\circ}$ fire burns. Similarly, in a group of eight patients, pain weakened quickly, and the epithelium was restored within one week [177].

Application of $20 \%$ horse colostrum emulsion (twice a day for 30 days) resulted in greater softening, moisturizing, soothing, and anti-inflammatory effects than observed for commonly available emulsions in seven patients with moderate atopic dermatitis compared to a control group of 10 healthy people. No side effects were observed, and erythema and pruritus decreased [177]. 
A liposomal gel containing $20 \%$ horse colostrum resulted in total or partial improvement of skin healing and skin repair in ten patients with ulcerative skin lesions treated twice daily for 20 days [177].

Irrespective of the composition, cosmetic formulations based on a combination of horse colostrum and horse milk demonstrate a number of skin benefits, including antiaging, moisturizing, protective, tensio-distensive, tonic, smoothing, anti-irritant, emollient, bleaching, decongestant, and sebostatic activities [177].

Another interesting patent study concerns the use of fermented horse colostrum in the case of atopic dermatitis. In this case, the colostrum was treated with lactic acid bacteria: Lactobacillus delbrueckii subsp. bulgaricus (ATCC 11842), Streptococcus thermophilus (ATCC 19258), and Lactobacillus rhamnosus GG, (ATCC 53103). The results indicate excellent moisturizing and anti-inflammatory properties, suggesting that the substance in question can be used to alleviate symptoms associated with atopic dermatitis, such as atopy and psoriasis [178].

A Korean patent describes the use of fermented colostrum as an anti-acne treatment. The specific active substance contained in colostrum, resulting from fermentation, appears to demonstrate excellent antibacterial effects against acne bacteria [179].

Another product containing bovine or equine colostrum, hyaluronic acid or its salt, and other substances such as olive oil (Olea europea) or vitamin E was found to reduce skin sagging, improve skin elasticity and tension, and demonstrate moisturizing and antioxidant properties when applied to the facial skin of elderly participants. Treatment also appeared to reduce the appearance of liver spots to a slight degree [180].

One patent presents a method of producing whitening cosmetics in which colostrum albumin is combined with arbutin, a whitening agent [181].

\section{Conclusions}

The broad spectrum of biological properties of milk and colostrum is undoubtedly related to their rich composition, especially in whey proteins, such as $\alpha$-lactalbumin, $\beta$ lactoglobulin, lactoferrin, lactoperoxidase, lysozyme, immunoglobulins. Milk proteins enjoy unflagging interest among medical scientists not only because of their activities but also because of their natural origin and non-toxicity. These ingredients are considered in treating skin diseases, restoring immunity, fighting cancer, and combating microorganisms. Despite the multitude of studies on milk raw materials, there are few clinical trials confirming their effectiveness. Milk-based products appear to be used more often as dietary supplements than as medications.

It is also important to note that differences in the composition of milk between animal species may influence their therapeutic value. As bovine milk has been quite exhaustively studied, future research should be directed towards the milk from other species: sheep, goats, or camels.

Among milk raw materials, colostrum deserves special attention. Its complex composition has been found to be safe for use in people and to give excellent results in rebuilding immunity, as well as its use as a therapeutic agent in dermatology and an active ingredient of cosmetics. Topically applied formulations containing colostrum support healing processes of burn wounds, ulcers, and sunburns. They also appear to be effective at treating skin diseases, such as acne vulgaris, plaque psoriasis, and contact lesions. However, most research concerns the synergistic effects yielded by the combination of milk-derived ingredients/products and other active substances, like vitamin E, zinc, arbutin, hyaluronic acid, which does not allow for unequivocal conclusions about the action of the milk-based products themselves. Therefore, clinical trials are needed on a separated from a single milk ingredient or milk/colostrum products without any other active additives.

Funding: This research was funded by the Medical University of Lodz (grant No. 503/3-066-02/ 503-31-001).

Conflicts of Interest: The authors declare no conflict of interest. 


\section{References}

1. Jenness, R. Composition of Milk. Fundam. Dairy Chem. 1988, 1-38. [CrossRef]

2. Audic, J.-L.; Chaufer, B.; Daufin, G. Non-Food Applications of Milk Components and Dairy Co-Products: A Review. Lait 2003, 83, 417-438. [CrossRef]

3. Luisa, B.G. Handbook of Milk Composition; Elsevier: Amsterdam, The Netherlands, 1995; ISBN 978-0-08-053311-7.

4. Ballard, O.; Morrow, A.L. Human Milk Composition: Nutrients and Bioactive Factors. Pediatric Clin. N. Am. 2013, 60, 49-74. [CrossRef]

5. Vollmer, D.; West, V.; Lephart, E. Enhancing Skin Health: By Oral Administration of Natural Compounds and Minerals with Implications to the Dermal Microbiome. Int. J. Mol. Sci. 2018, 19, 3059. [CrossRef] [PubMed]

6. McGrath, B.A.; Fox, P.F.; McSweeney, P.L.H.; Kelly, A.L. Composition and Properties of Bovine Colostrum: A Review. Dairy Sci. Technol. 2016, 96, 133-158. [CrossRef]

7. Bergman, A.J.; Turner, C.W. The Composition of the Colostrum of the Dairy Goat. J. Dairy Sci. 1937, 20, 37-45. [CrossRef]

8. Harjanti, D.W.; Ciptaningtyas, R.; Al-Baarri, A.N.; Kusumanti, E. Isolation and Identification of Lactoferrin and Lactoperoxidase from the Colostrum of Indonesian Ettawa Crossbred Goat. Adv. Sci. Lett. 2017, 23, 3321-3324. [CrossRef]

9. Rashida, K.; Ahmed, T.; Mirza, B. Comparative Analysis of Quality of Milk Collected from Buffalo, Cow, Goat and Sheep of Rawalpindi/Islamabad Region in Pakistan. Asian J. Plant Sci. 2004, 3. [CrossRef]

10. Haenlain, G.F.W. Nutritional Value of Dairy Products of Ewe and Goat Milk; International Dairy Federation: Brussels, Belgium, 1996.

11. Wendorff, W.L.; Haenlein, G.F.W. Sheep Milk-Composition and Nutrition. In Handbook of Milk of Non-Bovine Mammals; John Wiley \& Sons: Hoboken, NJ, USA, 2017; pp. 210-221. [CrossRef]

12. Anifantakis, E.M. Comparison of the Physico-Chemical Properties of Ewes' and Cows' Milk; FIL-IDF. Secretariat General; International Dairy Federation: Belgium, Brussels, 1986.

13. Park, Y.W.; Juárez, M.; Ramos, M.; Haenlein, G.F.W. Physico-Chemical Characteristics of Goat and Sheep Milk. Small Rumin. Res. 2007, 68, 88-113. [CrossRef]

14. Park, Y.W. (Ed.) Bioactive Components in Milk and Dairy Products; Wiley-Blackwell: Ames, IA, USA, 2009; ISBN 978-0-8138-1982-2.

15. Gobbetti, M.; Stepaniak, L.; De Angelis, M.; Corsetti, A.; Di Cagno, R. Latent Bioactive Peptides in Milk Proteins: Proteolytic Activation and Significance in Dairy Processing. Crit. Rev. Food Sci. Nutr. 2002, 42, 223-239. [CrossRef]

16. Clare, D.A.; Swaisgood, H.E. Bioactive Milk Peptides: A Prospectus. J. Dairy Sci. 2000, 83, 1187-1195. [CrossRef]

17. Cheema, M.; Hristov, A.N.; Harte, F.M. The Binding of Orally Dosed Hydrophobic Active Pharmaceutical Ingredients to Casein Micelles in Milk. J. Dairy Sci. 2017, 100, 8670-8679. [CrossRef]

18. Horne, D.S. Analytical Methods I Light Scattering Techniques. In Encyclopedia of Dairy Sciences, 2nd ed.; Fuquay, J.W., Ed.; Academic Press: San Diego, CA, USA, 2011; pp. 133-140. ISBN 978-0-12-374407-4.

19. Byun, J.S.; Lee, S.S. Effect of Soybeans and Sword Beans on Bone Metabolism in a Rat Model of Osteoporosis. Ann. Nutr. Metab. 2010, 56, 106-112. [CrossRef]

20. Milan, A.M.; Waddington, R.J.; Embery, G. Fluoride Alters Casein Kinase II and Alkaline Phosphatase Activity in Vitro with Potential Implications for Dentine Mineralization. Arch. Oral Biol. 2001, 46, 343-351. [CrossRef]

21. Meisel, H. Biochemical Properties of Bioactive Peptides Derived from Milk Proteins: Potential Nutraceuticals for Food and Pharmaceutical Applications. Livest. Prod. Sci. 1997, 50, 125-138. [CrossRef]

22. Park, Y.; Haenlein, G.F.W.; Wendorff, W. Handbook of Milk of Non-Bovine Mammals, 2nd ed.; John Wiley \& Sons: Hoboken, NJ, USA, 2017; ISBN 978-1-119-11027-9.

23. Moatsou, G.; Samolada, M.; Katsabeki, A.; Anifantakis, E. Casein Fraction of Ovine Milk from Indigenous Greek Breeds. Lait 2004, 84, 285-296. [CrossRef]

24. Al-Saadi, J.M.S.; Deeth, H.C. Preparation and Functional Properties of Protein Coprecipitate from Sheep Milk. Int. J. Dairy Technol. 2011, 64, 461-466. [CrossRef]

25. Levieux, D.; Morgan, F.; Geneix, N.; Masle, I.; Bouvier, F. Caprine Immunoglobulin G, Beta-Lactoglobulin, Alpha-Lactalbumin and Serum Albumin in Colostrum and Milk during the Early Post Partum Period. J. Dairy Res. 2002, 69, 391-399. [CrossRef]

26. Perez, M.D.; Sanchez, L.; Aranda, P.; Ena, J.M.; Oria, R.; Calvo, M. Synthesis and Evolution of Concentration of Beta-Lactoglobulin and Alpha-Lactalbumin from Cow and Sheep Colostrum and Milk throughout Early Lactation. Cell. Mol. Biol. 1990, 36, 205-212. [PubMed]

27. Ruprichova, L.; Kralova, M.; Borkovcova, I.; Vorlova, L.; Bedanova, I. Determination of Whey Proteins in Different Types of Milk. Acta Veterinaria Brno 2014, 83, 67-72. [CrossRef]

28. Feeney, S.; Morrin, S.T.; Joshi, L.; Hickey, R.M. The Role of Immunoglobulins from Bovine Colostrum and Milk in Human Health Promotion. In Novel Proteins for Food, Pharmaceuticals and Agriculture; John Wiley \& Sons, Ltd.: Hoboken, NJ, USA, 2018; pp. 291-314. ISBN 978-1-119-38533-2.

29. Atkinson, D.J.; von Keyserlingk, M.A.G.; Weary, D.M. Benchmarking Passive Transfer of Immunity and Growth in Dairy Calves. J. Dairy Sci. 2017, 100, 3773-3782. [CrossRef]

30. Roginski, H.; Fuquay, J.W.; Fox, P.F. Encyclopedia of Dairy Sciences; Academic Press: Cambridge, MA, USA, 2003; ISBN 978-0-12-227235-6.

31. Stelwagen, K.; Carpenter, E.; Haigh, B.; Hodgkinson, A.; Wheeler, T.T. Immune Components of Bovine Colostrum and Milk. J. Anim. Sci. 2009, 87, 3-9. [CrossRef] 
32. Kehoe, S.I.; Jayarao, B.M.; Heinrichs, A.J. A Survey of Bovine Colostrum Composition and Colostrum Management Practices on Pennsylvania Dairy Farms1. J. Dairy Sci. 2007, 90, 4108-4116. [CrossRef] [PubMed]

33. Mesmin, C.; Fenaille, F.; Becher, F.; Tabet, J.-C.; Ezan, E. Identification and Characterization of Apelin Peptides in Bovine Colostrum and Milk by Liquid Chromatography-Mass Spectrometry. J. Proteome Res. 2011, 10, 5222-5231. [CrossRef] [PubMed]

34. Recio, I.; de la Fuente, M.A.; Juárez, M.; Ramos, M. Bioactive Components in Sheep Milk. In Bioactive Components in Milk and Dairy Products; John Wiley \& Sons, Ltd.: Hoboken, NJ, USA, 2009; pp. 83-104. ISBN 978-0-8138-2150-4.

35. Tabatabaei, S.; Nikbakht, G.; Vatankhah, M.; Sharifi, H.; Alidadi, N. Variation in Colostral Immunoglobulin G Concentration in Fat Tailed Sheep and Evaluation of Methods for Estimation of Colostral Immunoglobulin Content. Acta Veterinaria Brno 2013, 82, 271-275. [CrossRef]

36. Navarro, F.; Galan-Malo, P.; Pérez, M.D.; Abecia, J.-A.; Mata, L.; Calvo, M.; Sánchez, L. Lactoferrin and IgG Levels in Ovine Milk throughout Lactation: Correlation with Milk Quality Parameters. Small Rumin. Res. 2018, 168, 12-18. [CrossRef]

37. Hernández-Castellano, L.E.; Almeida, A.M.; Renaut, J.; Argüello, A.; Castro, N. A Proteomics Study of Colostrum and Milk from the Two Major Small Ruminant Dairy Breeds from the Canary Islands: A Bovine Milk Comparison Perspective. J. Dairy Res. 2016, 83, 366-374. [CrossRef] [PubMed]

38. Farrell, H.M.; Jimenez-Flores, R.; Bleck, G.T.; Brown, E.M.; Butler, J.E.; Creamer, L.K.; Hicks, C.L.; Hollar, C.M.; Ng-Kwai-Hang, K.F.; Swaisgood, H.E. Nomenclature of the Proteins of Cows' Milk-Sixth Revision. J. Dairy Sci. 2004, 87, 1641-1674. [CrossRef]

39. Madureira, A.R.; Pereira, C.I.; Gomes, A.M.P.; Pintado, M.E.; Xavier Malcata, F. Bovine Whey Proteins-Overview on Their Main Biological Properties. Food Res. Int. 2007, 40, 1197-1211. [CrossRef]

40. Smithers, G.W. Whey and Whey Proteins-From 'Gutter-to-Gold'. Int. Dairy J. 2008, 18, 695-704. [CrossRef]

41. Wang, B.; Timilsena, Y.P.; Blanch, E.; Adhikari, B. Lactoferrin: Structure, Function, Denaturation and Digestion. Crit. Rev. Food Sci. Nutr. 2019, 59, 580-596. [CrossRef]

42. Mulder, A.M.; Connellan, P.A.; Oliver, C.J.; Morris, C.A.; Stevenson, L.M. Bovine Lactoferrin Supplementation Supports Immune and Antioxidant Status in Healthy Human Males. Nutr. Res. 2008, 28, 583-589. [CrossRef]

43. Mehra, R.; Singh, R.; Nayan, V.; Buttar, H.S.; Kumar, N.; Kumar, S.; Bhardwaj, A.; Kaushik, R.; Kumar, H. Nutritional Attributes of Bovine Colostrum Components in Human Health and Disease: A Comprehensive Review. Food Biosci. 2021, 40, 100907. [CrossRef]

44. McSweeney, P.L.H.; Fox, P.F. (Eds.) Advanced Dairy Chemistry: Volume 1A: Proteins: Basic Aspects, 4th ed.; Springer: Boston, MA, USA, 2013; ISBN 978-1-4614-4713-9.

45. Hernández-Ledesma, B.; Ramos, M.; Gómez-Ruiz, J.Á. Bioactive Components of Ovine and Caprine Cheese Whey. Small Rumin. Res. 2011, 101, 196-204. [CrossRef]

46. Blum, J.W.; Hammon, H. Colostrum Effects on the Gastrointestinal Tract, and on Nutritional, Endocrine and Metabolic Parameters in Neonatal Calves. Livest. Prod. Sci. 2000, 66, 151-159. [CrossRef]

47. Campbell, P.G.; Baumrucker, C.R. Insulin-like Growth Factor-I and Its Association with Binding Proteins in Bovine Milk. J. Endocrinol. 1989, 120, 21-29. [CrossRef] [PubMed]

48. Elfstrand, L.; Lindmark-Månsson, H.; Paulsson, M.; Nyberg, L.; Åkesson, B. Immunoglobulins, Growth Factors and Growth Hormone in Bovine Colostrum and the Effects of Processing. Int. Dairy J. 2002, 12, 879-887. [CrossRef]

49. Ginjala, V.; Pakkanen, R. Determination of Transforming Growth Factor-B1 (TGF-B1) and Insulin-Like Growth Factor 1 (IGF-1) in Bovine Colostrum Samples. J. Immunoass. 1998, 19, 195-207. [CrossRef] [PubMed]

50. Hadsell, D.L.; Baumrucker, C.R.; Kensinger, R.S. Effects of Elevated Blood Insulin-like Growth Factor-I (IGF-I) Concentration upon IGF-I in Bovine Mammary Secretions during the Colostrum Phase. J. Endocrinol. 1993, 137, 223-230. [CrossRef] [PubMed]

51. Malven, P.V.; Head, H.H.; Collier, R.J.; Buonomo, F.C. Periparturient Changes in Secretion and Mammary Uptake of Insulin and in Concentrations of Insulin and Insulin-like Growth Factors in Milk of Dairy Cows. J. Dairy Sci. 1987, 70, 2254-2265. [CrossRef]

52. Marcotty, C.; Frankenne, F.; Van Beeumen, J.; Maghuin-Rogister, G.; Hennen, G. Insulin-like Growth Factor I (IGF-I) from Cow Colostrum: Purification and Characterization. Growth Regul. 1991, 1, 56-61.

53. Oda, S.; Satoh, H.; Sugawara, T.; Matsunaga, N.; Kuhara, T.; Katoh, K.; Shoji, Y.; Nihei, A.; Ohta, M.; Sasaki, Y. Insulin-like Growth Factor-I, GH, Insulin and Glucagon Concentrations in Bovine Colostrum and in Plasma of Dairy Cows and Neonatal Calves around Parturition. Comp. Biochem. Physiol. Comp. Physiol. 1989, 94, 805-808. [CrossRef]

54. Ontsouka, C.E.; Bruckmaier, R.M.; Blum, J.W. Fractionized Milk Composition during Removal of Colostrum and Mature Milk. J. Dairy Sci. 2003, 86, 2005-2011. [CrossRef]

55. Sejrsen, K.; Pedersen, L.O.; Vestergaard, M.; Purup, S. Biological Activity of Bovine Milk: Contribution of IGF-I and IGF Binding Proteins. Livest. Prod. Sci. 2001, 70, 79-85. [CrossRef]

56. Skaar, T.C.; Vega, J.R.; Pyke, S.N.; Baumrucker, C.R. Changes in Insulin-like Growth Factor-Binding Proteins in Bovine Mammary Secretions Associated with Pregnancy and Parturition. J. Endocrinol. 1991, 131, 127-133. [CrossRef] [PubMed]

57. Sparks, A.L.; Kirkpatrick, J.G.; Chamberlain, C.S.; Waldner, D.; Spicer, L.J. Insulin-like Growth Factor-I and Its Binding Proteins in Colostrum Compared to Measures in Serum of Holstein Neonates. J. Dairy Sci. 2003, 86, 2022-2029. [CrossRef]

58. Vacher, P.-Y.; Blum, J.W. Age-Dependency of Insulin-like Growth Factor I, Insulin, Protein and Immunoglobulin Concentrations and Gamma-Glutamyl-Transferase Activity in First Colostrum of Dairy Cows. Milchwissenschaft 1993, 48, 423-426.

59. Simmen, F.A.; Simmen, R.C.; Reinhart, G. Maternal and Neonatal Somatomedin C/Insulin-like Growth Factor-I (IGF-I) and IGF Binding Proteins during Early Lactation in the Pig. Dev. Biol. 1988, 130, 16-27. [CrossRef] 
60. Hall, D.G.; Holst, P.J.; Shutt, D.A. The Effect of Nutritional Supplements in Late Pregnancy on Ewe Colostrum Production Plasma Progesterone and IGF-1 Concentrations. Aust. J. Agric. Res. 1992, 43, 325-337. [CrossRef]

61. Prosser, C.G.; Royle, C.; Fleet, I.R.; Mepham, T.B. The Galactopoietic Effect of Bovine Growth Hormone in Goats Is Associated with Increased Concentrations of Insulin-like Growth Factor-I in Milk and Mammary Tissue. J. Endocrinol. 1991, 128, 457-463. [CrossRef]

62. Prosser, C.G.; Fleet, I.R.; Davis, A.J.; Heap, R.B. Mechanism of Secretion of Plasma Insulin-like Growth Factor-I into Milk of Lactating Goats. J. Endocrinol. 1991, 131, 459-466. [CrossRef]

63. Prosser, C.G.; Fleet, I.R.; Corps, A.N.; Froesch, E.R.; Heap, R.B. Increase in Milk Secretion and Mammary Blood Flow by Intra-Arterial Infusion of Insulin-like Growth Factor-I into the Mammary Gland of the Goat. J. Endocrinol. 1990, 126, 437-443. [CrossRef] [PubMed]

64. Yagi, H.; Suzuki, S.; Noji, T.; Nagashima, K.; Kuroume, T. Epidermal Growth Factor in Cow's Milk and Milk Formulas. Acta Paediatr. 1986, 75, 233-235. [CrossRef] [PubMed]

65. Iacopetta, B.J.; Grieu, F.; Horisberger, M.; Sunahara, G.I. Epidermal Growth Factor in Human and Bovine Milk. Acta Paediatr. 1992, 81, 287-291. [CrossRef] [PubMed]

66. Gow, C.B.; Singleton, D.J.; Silvapulle, M.J.; Moore, G.P.M. Lack of Effect of Epidermal Growth Factor Treatment in Late-Pregnant Ewes on Subsequent Lactation. J. Dairy Res. 1991, 58, 1-11. [CrossRef] [PubMed]

67. Pakkanen, R. Determination of Transforming Growth Factor-Beta 2 (TGF-Beta 2) in Bovine Colostrum Samples. J. Immunoass. 1998, 19, 23-37. [CrossRef]

68. Gobbetti, M.; Minervini, F.; Rizzello, C.G. Angiotensin I-Converting-Enzyme-Inhibitory and Antimicrobial Bioactive Peptides. Int. J. Dairy Technol. 2004, 57, 173-188. [CrossRef]

69. Gobbetti, M.; Minervini, F.; Rizzello, C.G. Bioactive Peptides in Dairy Products. In Handbook of Food Products Manufacturing; John Wiley \& Sons, Ltd.: Hoboken, NJ, USA, 2006; pp. 489-517. ISBN 978-0-470-11355-4.

70. FitzGerald, R.J.; Meisel, H. Milk Protein-Derived Peptide Inhibitors of Angiotensin-I-Converting Enzyme. Br. J. Nutr. 2000, 84, 33-37. [CrossRef]

71. Brody, E.P. Biological Activities of Bovine Glycomacropeptide. Br. J. Nutr. 2000, 84, S39-S46. [CrossRef]

72. Manso, M. Casein Macropeptides from Cheese Whey: Physicochemical, Biological, Nutritional, and Technological Features for Possible Uses. Food Rev. Int. 2004, 20, 329-355. [CrossRef]

73. Song, J.; Gao, J.; Du, M.; Mao, X. Casein Glycomacropeptide Hydrolysates Ameliorate Hepatic Insulin Resistance of C57BL/6J Mice Challenged with High-Fat Diet. J. Funct. Foods 2018, 45, 190-198. [CrossRef]

74. Li, T.; Gao, D.; Du, M.; Cheng, X.; Mao, X. Casein Glycomacropeptide Hydrolysates Inhibit PGE2 Production and COX2 Expression in LPS-Stimulated RAW 264.7 Macrophage Cells via Akt Mediated NF-KB and MAPK Pathways. Available online: https:/ / pubmed-1ncbi-1nlm-1nih-1gov-12ik8q6jo0903.han.cib.umed.lodz.pl/29666854/ (accessed on 27 May 2020).

75. Yuan, Q.; Zhan, B.; Chang, R.; Du, M.; Mao, X. Antidiabetic Effect of Casein Glycomacropeptide Hydrolysates on High-Fat Diet and STZ-Induced Diabetic Mice via Regulating Insulin Signaling in Skeletal Muscle and Modulating Gut Microbiota. Nutrients 2020, 12, 220. [CrossRef]

76. Semo, E.; Kesselman, E.; Danino, D.; Livney, Y.D. Casein Micelle as a Natural Nano-Capsular Vehicle for Nutraceuticals. Food Hydrocoll. 2007, 21, 936-942. [CrossRef]

77. Ma, J.; An, W.; Xu, Q.; Fan, Q.; Wang, Y. Antibacterial Casein-Based ZnO Nanocomposite Coatings with Improved Water Resistance Crafted via Double in Situ Route. Prog. Org. Coat. 2019, 134, 40-47. [CrossRef]

78. Cheng, H.; Dong, H.; Liang, L. A Comparison of $\beta$-Casein Complexes and Micelles as Vehicles for Trans-/Cis-Resveratrol. Food Chem. 2020, 330, 127209. [CrossRef]

79. Razmi, M.; Divsalar, A.; Saboury, A.A.; Izadi, Z.; Haertlé, T.; Mansuri-Torshizi, H. Beta-Casein and Its Complexes with Chitosan as Nanovehicles for Delivery of a Platinum Anticancer Drug. Colloids Surf. B Biointerfaces 2013, 112, 362-367. [CrossRef] [PubMed]

80. Chatterton, D.E.W.; Smithers, G.; Roupas, P.; Brodkorb, A. Bioactivity of $\beta$-Lactoglobulin and $\alpha$-Lactalbumin-Technological Implications for Processing. Int. Dairy J. 2006, 16, 1229-1240. [CrossRef]

81. Markus, C.R.; Olivier, B.; De Haan, E.H. Whey Protein Rich in $\alpha$-Lactalbumin Increases the Ratio of Plasma Tryptophan to the Sum of the Other Large Neutral Amino Acids and Improves Cognitive Performance in Stress-Vulnerable Subjects. Am. J. Clin. Nutr. 2002, 75, 1051-1056. [CrossRef] [PubMed]

82. Garg, S.; Nurgali, K.; Mishra, V.K. Food Proteins as Source of Opioid Peptides-A Review. Curr. Med. Chem. 2016, 23, 893-910. [CrossRef] [PubMed]

83. Tyagi, A.; Daliri, E.B.-M.; Kwami Ofosu, F.; Yeon, S.-J.; Oh, D.-H. Food-Derived Opioid Peptides in Human Health: A Review. Int. J. Mol. Sci. 2020, 21, 8825. [CrossRef]

84. Pellegrini, A.; Thomas, U.; Bramaz, N.; Hunziker, P. Isolation and Identification of Three Bactericidal Domains in the Bovine $\alpha$-Lactalbumin Molecule. Biochim. Biophys. Acta 1999, 1426, 439-448. [CrossRef]

85. Mok, K.H.; Pettersson, J.; Orrenius, S.; Svanborg, C. HAMLET, Protein Folding, and Tumor Cell Death. Biochem. Biophys. Res. Commun. 2007, 354, 1-7. [CrossRef]

86. Mossberg, A.-K.; Hun Mok, K.; Morozova-Roche, L.A.; Svanborg, C. Structure and Function of Human $\alpha$-Lactalbumin Made Lethal to Tumor Cells (HAMLET)-Type Complexes. FEBS J. 2010, 277, 4614-4625. [CrossRef] [PubMed] 
87. Gustafsson, L.; Leijonhufvud, I.; Aronsson, A.; Mossberg, A.-K.; Svanborg, C. Treatment of Skin Papillomas with Topical Alpha-Lactalbumin-Oleic Acid. N. Engl. J. Med. 2004, 350, 2663-2672. [CrossRef] [PubMed]

88. Mossberg, A.-K.; Wullt, B.; Gustafsson, L.; Månsson, W.; Ljunggren, E.; Svanborg, C. Bladder Cancers Respond to Intravesical Instillation of HAMLET (Human Alpha-Lactalbumin Made Lethal to Tumor Cells). Int. J. Cancer 2007, 121, 1352-1359. [CrossRef] [PubMed]

89. Creamer, L.K.; Harris, D.P. Relationship between Milk Protein Polymorphism and Physico-Chemical Properties; New Z.D.R.I.; International Dairy Federation: Brussels, Belgium, 1997.

90. Kim, J.; Ko, Y.; Park, Y.-K.; Kim, N.-I.; Ha, W.-K.; Cho, Y. Dietary Effect of Lactoferrin-Enriched Fermented Milk on Skin Surface Lipid and Clinical Improvement of Acne Vulgaris. Nutrition 2010, 26, 902-909. [CrossRef]

91. Bogahawaththa, D.; Chandrapala, J.; Vasiljevic, T. Thermal Denaturation of Bovine $\beta$-Lactoglobulin in Different Protein Mixtures in Relation to Antigenicity. Int. Dairy J. 2019, 91, 89-97. [CrossRef]

92. Liu, H.C.; Chen, W.L.; Mao, S.J.T. Antioxidant Nature of Bovine Milk Beta-Lactoglobulin. J. Dairy Sci. 2007, 90, 547-555. [CrossRef]

93. Hernández-Ledesma, B.; Dávalos, A.; Bartolomé, B.; Amigo, L. Preparation of Antioxidant Enzymatic Hydrolysates from $\alpha$-Lactalbumin and $\beta$-Lactoglobulin. Identification of Active Peptides by HPLC-MS/MS. J. Agric. Food Chem. 2005, 53, 588-593. [CrossRef]

94. McIntosh, G.H.; Royle, P.J.; Le Leu, R.K.; Regester, G.O.; Johnson, M.A.; Grinsted, R.L.; Kenward, R.S.; Smithers, G.W. Whey Proteins as Functional Food Ingredients? Int. Dairy J. 1998, 8, 425-434. [CrossRef]

95. Wanders, D.; Hobson, K.; Ji, X. Methionine Restriction and Cancer Biology. Nutrients 2020, 12, 684. [CrossRef]

96. Pan, Y.; Shiell, B.; Wan, J.; Coventry, M.J.; Michalski, W.P.; Leeb, A.; Roginski, H. The Molecular Characterisation and Antimicrobial Properties of Amidated Bovine $\beta$-Lactoglobulin. Int. Dairy J. 2007, 17, 1450-1459. [CrossRef]

97. Oevermann, A.; Engels, M.; Thomas, U.; Pellegrini, A. The Antiviral Activity of Naturally Occurring Proteins and Their Peptide Fragments after Chemical Modification. Antivir. Res. 2003, 59, 23-33. [CrossRef]

98. Czosnykowska-Łukacka, M.; Orczyk-Pawiłowicz, M.; Broers, B.; Królak-Olejnik, B. Lactoferrin in Human Milk of Prolonged Lactation. Nutrients 2019, 11, 2350. [CrossRef]

99. Rahman, M.; Kim, W.-S.; Kumura, H.; Shimazaki, K. Bovine Lactoferrin Region Responsible for Binding to Bifidobacterial Cell Surface Proteins. Biotechnol. Lett. 2009, 31, 863-868. [CrossRef]

100. Steijns, J.M.; van Hooijdonk, A.C.M. Occurrence, Structure, Biochemical Properties and Technological Characteristics of Lactoferrin. Br. J. Nutr. 2000, 84, 11-17. [CrossRef]

101. Bobbarala, V. A Search for Antibacterial Agents; InTech: Rijeka, Croatia, 2012; ISBN 978-953-51-0724-8.

102. Baker, E.N.; Baker, H.M. Molecular Structure, Binding Properties and Dynamics of Lactoferrin. Cell. Mol. Life Sci. 2005, 62, 2531. [CrossRef]

103. Legrand, D.; Pierce, A.; Elass, E.; Carpentier, M.; Mariller, C.; Mazurier, J. Lactoferrin Structure and Functions. Bioact. Compon. Milk 2008, 163-194. [CrossRef]

104. Orsi, N. The Antimicrobial Activity of Lactoferrin: Current Status and Perspectives. Biometals 2004, 17, 189-196. [CrossRef]

105. Żelechowska, P.; Agier, J.; Brzezińska-Błaszczyk, E. Endogenous Antimicrobial Factors in the Treatment of Infectious Diseases. Cent. Eur. J. Immunol. 2016, 41, 419-425. [CrossRef]

106. Zimecki, M.; Spiegel, K.; Właszczyk, A.; Kübler, A.; Kruzel, M.L. Lactoferrin Increases the Output of Neutrophil Precursors and Attenuates the Spontaneous Production of TNF-Alpha and IL-6 by Peripheral Blood Cells. Arch. Immunol. Exp. 1999, 47, 113-118.

107. Yamauchi, K.; Wakabayashi, H.; Hashimoto, S.; Teraguchi, S.; Hayasawa, H.; Tomita, M. Effects of Orally Administered Bovine Lactoferrin on the Immune System of Healthy Volunteers. Adv. Exp. Med. Biol. 1998, 443, 261-265. [CrossRef] [PubMed]

108. Wakabayashi, H.; Yamauchi, K.; Takase, M. Lactoferrin Research, Technology and Applications. Int. Dairy J. 2006, 16, 1241-1251. [CrossRef]

109. Van der Strate, B.W.; Beljaars, L.; Molema, G.; Harmsen, M.C.; Meijer, D.K. Antiviral Activities of Lactoferrin. Antivir. Res. 2001, 52, 225-239. [CrossRef]

110. Van der Kraan, M.I.A.; Groenink, J.; Nazmi, K.; Veerman, E.C.I.; Bolscher, J.G.M.; Nieuw Amerongen, A.V. Lactoferrampin: A Novel Antimicrobial Peptide in the N1-Domain of Bovine Lactoferrin. Peptides 2004, 25, 177-183. [CrossRef] [PubMed]

111. Superti, F.; Ammendolia, M.G.; Valenti, P.; Seganti, L. Antirotaviral Activity of Milk Proteins: Lactoferrin Prevents Rotavirus Infection in the Enterocyte-like Cell Line HT-29. Med. Microbiol. Immunol. 1997, 186, 83-91. [CrossRef] [PubMed]

112. Siqueiros-Cendón, T.; Arévalo-Gallegos, S.; Iglesias-Figueroa, B.F.; García-Montoya, I.A.; Salazar-Martínez, J.; Rascón-Cruz, Q. Immunomodulatory Effects of Lactoferrin. Acta Pharm. Sin. 2014, 35, 557-566. [CrossRef]

113. Seganti, L.; Di Biase, A.M.; Marchetti, M.; Pietrantoni, A.; Tinari, A.; Superti, F. Antiviral Activity of Lactoferrin towards Naked Viruses. Biometals 2004, 17, 295-299. [CrossRef]

114. Saraceno, R.; Gramiccia, T.; Chimenti, S.; Valenti, P.; Pietropaoli, M.; Bianchi, L. Topical Lactoferrin Can Improve Stable Psoriatic Plaque. G. Ital. Dermatol. Venereol. 2014, 149, 335-340.

115. Superti, F. Lactoferrin from Bovine Milk: A Protective Companion for Life. Nutrients 2020, 12, 2562. [CrossRef]

116. Drago-Serrano, M.E.; de la Garza-Amaya, M.; Luna, J.S.; Campos-Rodríguez, R. Lactoferrin-Lipopolysaccharide (LPS) Binding as Key to Antibacterial and Antiendotoxic Effects. Int. Immunopharmacol. 2012, 12, 1-9. [CrossRef]

117. Wakabayashi, H.; Uchida, K.; Yamauchi, K.; Teraguchi, S.; Hayasawa, H.; Yamaguchi, H. Lactoferrin given in Food Facilitates Dermatophytosis Cure in Guinea Pig Models. J. Antimicrob. Chemother. 2000, 46, 595-602. [CrossRef] 
118. Fernandes, K.E.; Carter, D.A. The Antifungal Activity of Lactoferrin and Its Derived Peptides: Mechanisms of Action and Synergy with Drugs against Fungal Pathogens. Front. Microbiol. 2017, 8, 2. [CrossRef] [PubMed]

119. Leboffe, L.; Giansanti, F.; Antonini, G. Antifungal and Antiparasitic Activities of Lactoferrin. Anti Infect. Agents Med. Chem. 2009, 8, 114-127. [CrossRef]

120. Berlutti, F.; Pantanella, F.; Natalizi, T.; Frioni, A.; Paesano, R.; Polimeni, A.; Valenti, P. Antiviral Properties of Lactoferrin-A Natural Immunity Molecule. Molecules 2011, 16, 6992-7018. [CrossRef]

121. Redwan, E.M.; Uversky, V.N.; El-Fakharany, E.M.; Al-Mehdar, H. Potential Lactoferrin Activity against Pathogenic Viruses. Comptes Rendus Biol. 2014, 337, 581-595. [CrossRef] [PubMed]

122. Shakibaei, M.; Frevert, U. Dual Interaction of the Malaria Circumsporozoite Protein with the Low Density Lipoprotein ReceptorRelated Protein (LRP) and Heparan Sulfate Proteoglycans. J. Exp. Med. 1996, 184, 1699-1711. [CrossRef] [PubMed]

123. Cirioni, O.; Giacometti, A.; Barchiesi, F.; Scalise, G. Inhibition of Growth of Pneumocystis Carinii by Lactoferrins Alone and in Combination with Pyrimethamine, Clarithromycin and Minocycline. J. Antimicrob. Chemother. 2000, 46, 577-582. [CrossRef] [PubMed]

124. León-Sicairos, N.; Reyes-López, M.; Ordaz-Pichardo, C.; de la Garza, M. Microbicidal Action of Lactoferrin and Lactoferricin and Their Synergistic Effect with Metronidazole in Entamoeba Histolytica. Biochem. Cell Biol. 2006, 84, 327-336. [CrossRef]

125. Weinberg, G.A. Iron Chelators as Therapeutic Agents against Pneumocystis Carinii. Antimicrob. Agents Chemother. 1994, 38, 997-1003. [CrossRef]

126. Jenssen, H.; Hancock, R. Antimicrobial Properties of Lactoferrin. Biochimie 2009, 91, 19-29. [CrossRef]

127. Superti, F.; Berlutti, F.; PAESANO, R. Structure and Activity of Lactoferrin-A Multi Functional Protective Agent for Human Health. Iron Metab. Dis. 2008, 8, 1-32.

128. Andersen, J.H.; Jenssen, H.; Gutteberg, T.J. Lactoferrin and Lactoferricin Inhibit Herpes Simplex 1 and 2 Infection and Exhibit Synergy When Combined with Acyclovir. Antivir. Res. 2003, 58, 209-215. [CrossRef]

129. Hendrixson, D.R.; Qiu, J.; Shewry, S.C.; Fink, D.L.; Petty, S.; Baker, E.N.; Plaut, A.G.; St Geme, J.W. Human Milk Lactoferrin Is a Serine Protease That Cleaves Haemophilus Surface Proteins at Arginine-Rich Sites. Mol. Microbiol. 2003, 47, 607-617. [CrossRef]

130. Singh, H.; Ye, A.; Horne, D. Structuring Food Emulsions in the Gastrointestinal Tract to Modify Lipid Digestion. Prog. Lipid Res. 2009, 48, 92-100. [CrossRef]

131. Diarra, M.S.; Petitclerc, D.; Lacasse, P. Effect of Lactoferrin in Combination with Penicillin on the Morphology and the Physiology of Staphylococcus Aureus Isolated from Bovine Mastitis. J. Dairy Sci. 2002, 85, 1141-1149. [CrossRef]

132. Ishii, K.; Takamura, N.; Shinohara, M.; Wakui, N.; Shin, H.; Sumino, Y.; Ohmoto, Y.; Teraguchi, S.; Yamauchi, K. Long-Term Follow-up of Chronic Hepatitis C Patients Treated with Oral Lactoferrin for 12 Months. Hepatol. Res. Off. J. Jpn. Soc. Hepatol. 2003, 25, 226-233. [CrossRef]

133. Andersen, J.H.; Jenssen, H.; Sandvik, K.; Gutteberg, T.J. Anti-HSV Activity of Lactoferrin and Lactoferricin Is Dependent on the Presence of Heparan Sulphate at the Cell Surface. J. Med. Virol. 2004, 74, 262-271. [CrossRef]

134. Berkhout, B.; Floris, R.; Recio, I.; Visser, S. The Antiviral Activity of the Milk Protein Lactoferrin against the Human Immunodeficiency Virus Type 1. Biometals Int. J. Role Met. Ions Biol. Biochem. Med. 2004, 17, 291-294. [CrossRef]

135. Brock, J.H. The Physiology of Lactoferrin. Biochem. Cell Biol. 2002, 80, 1-6. [CrossRef]

136. Firestein, G.S.; Stanford, S.M. Mechanisms of Inflammation and Tissue Repair. In Goldman's Cecil Medicine, 26th ed.; Goldman, L., Schafer, A., Eds.; Elsevier: Alpharetta, GA, USA, 2019; Chapter 42; pp. 212-216. ISBN 978-0-323-55087-1.

137. Larkins, N. Potential Implications of Lactoferrin as a Therapeutic Agent. Am. J. Vet. Res. 2005, 66, 739-742. [CrossRef]

138. Fox, F.; Kelly, A.L. Indigenous Enzymes in Milk: Overview and Historical Aspects-Part 1 I Request PDF. Int. Dairy J. 2006, 16, 500-516. [CrossRef]

139. Garcia, H.S.; López-Hernandez, A.; Hill, C.G. 4.47-Enzyme Technology-Dairy Industry Applications. In Comprehensive Biotechnology, 2nd ed.; Moo-Young, M., Ed.; Academic Press: Burlington, VT, USA, 2011; pp. 567-574. ISBN 978-0-08-088504-9.

140. Özer, B. Natural Anti-Microbial Systems I Lactoperoxidase and Lactoferrin. In Encyclopedia of Food Microbiology, 2nd ed.; Batt, C.A., Tortorello, M.L., Eds.; Academic Press: Oxford, UK, 2014; pp. 930-935. ISBN 978-0-12-384733-1.

141. Pakkanen, R.; Aalto, J. Growth Factors and Antimicrobial Factors of Bovine Colostrum. Int. Dairy J. 1997, 7, 285-297. [CrossRef]

142. Seifu, E.; Buys, E.; Donkin, E. Significance of the Lactoperoxidase System in the Dairy Industry and Its Potential Applications: A Review. Trends Food Sci. Technol. 2005, 16, 137-154. [CrossRef]

143. Shin, K.; Hayasawa, H.; Lönnerdal, B. Inhibition of Escherichia Coli Respiratory Enzymes by the Lactoperoxidase-Hydrogen Peroxide-Thiocyanate Antimicrobial System. J. Appl. Microbiol. 2001, 90, 489-493. [CrossRef]

144. Belding, M.E.; Klebanoff, S.J.; Ray, C.G. Peroxidase-Mediated Virucidal Systems. Science 1970, 167, 195-196. [CrossRef]

145. Purdy, M.A.; Tenovuo, J.; Pruitt, K.M.; White, W.E. Effect of Growth Phase and Cell Envelope Structure on Susceptibility of Salmonella Typhimurium to the Lactoperoxidase-Thiocyanate-Hydrogen Peroxide System. Infect. Immun. 1983, 39, 1187-1195. [CrossRef]

146. El-Fakharany, E.M.; Abd-Elhamid, A.I.; El-Deeb, N.M. Preparation and Characterization of Novel Nanocombination of Bovine Lactoperoxidase with Dye Decolorizing and Anti-Bacterial Activity. Sci. Rep. 2019, 9, 8530. [CrossRef]

147. Hurley, W.L.; Theil, P.K. Perspectives on Immunoglobulins in Colostrum and Milk. Nutrients 2011, 3, 442-474. [CrossRef]

148. Czosnykowska-Łukacka, M.; Lis-Kuberka, J.; Królak-Olejnik, B.; Orczyk-Pawiłowicz, M. Changes in Human Milk Immunoglobulin Profile During Prolonged Lactation. Front. Pediatr. 2020, 8. [CrossRef] 
149. Gapper, L.W.; Copestake, D.E.J.; Otter, D.E.; Indyk, H.E. Analysis of Bovine Immunoglobulin G in Milk, Colostrum and Dietary Supplements: A Review. Anal. Bioanal. Chem. 2007, 389, 93-109. [CrossRef] [PubMed]

150. Korhonen, H. Milk-Derived Bioactive Peptides: From Science to Applications. J. Funct. Foods 2009, 1, 177-187. [CrossRef]

151. Chiang, B.H.; Su, C.K.; Tsai, G.J.; Tsao, G.T. Egg White Lysozyme Purification by Ultrafiltration and Affinity Chromatography. J. Food Sci. 2006, 58, 303-306. [CrossRef]

152. Cegielska-Radziejewska, R.; Lesnierowski, G.; Kijowski, J. Properties and Application of Egg White Lysozyme and Its Modified Preparations-A Review. Pol. J. Food Nutr. Sci. 2008, 58, 5-10.

153. Benkerroum, N. Antimicrobial Activity of Lysozyme with Special Relevance to Milk. Afr. J. Biotechnol. 2008, 7. [CrossRef]

154. Clementi, E.A.; Wilhelm, K.R.; Schleucher, J.; Morozova-Roche, L.A.; Hakansson, A.P. A Complex of Equine Lysozyme and Oleic Acid with Bactericidal Activity against Streptococcus Pneumoniae. PLoS ONE 2013, 8, e80649. [CrossRef]

155. Tripathy, N.; Ahmad, R.; Bang, S.H.; Min, J.; Hahn, Y.-B. Tailored Lysozyme-ZnO Nanoparticle Conjugates as Nanoantibiotics. Chem. Commun. 2014, 50, 9298-9301. [CrossRef] [PubMed]

156. Janusz, M.; Woszczyna, M.; Lisowski, M.; Kubis, A.; Macała, J.; Gotszalk, T.; Lisowski, J. Ovine Colostrum Nanopeptide Affects Amyloid Beta Aggregation. FEBS Lett. 2009, 583, 190-196. [CrossRef]

157. Kruzel, M.L.; Janusz, M.; Lisowski, J.; Fischleigh, R.V.; Georgiades, J.A. Towards an Understanding of Biological Role of Colostrinin Peptides. J. Mol. Neurosci. 2001, 17, 379-389. [CrossRef]

158. Boldogh, I.; Aguilera-Aguirre, L.; Bacsi, A.; Choudhury, B.K.; Saavedra-Molina, A.; Kruzel, M. Colostrinin Decreases Hypersensitivity and Allergic Responses to Common Allergens. Int. Arch. Allergy Immunol. 2008, 146, 298-306. [CrossRef]

159. Leszek, J.; Inglot, A.D.; Janusz, M.; Byczkiewicz, F.; Kiejna, A.; Georgiades, J.; Lisowski, J. Colostrinin Proline-Rich Polypeptide Complex from Ovine Colostrum-a Long-Term Study of Its Efficacy in Alzheimer's Disease. Med. Sci. Monit. 2002, 8 , PI93-PI96. [PubMed]

160. Mailloux, A.W.; Zhang, L.; Moscinski, L.; Bennett, J.M.; Yang, L.; Yoder, S.J.; Bloom, G.; Wei, C.; Wei, S.; Sokol, L.; et al. Fibrosis and Subsequent Cytopenias Are Associated with Basic Fibroblast Growth Factor-Deficient Pluripotent Mesenchymal Stromal Cells in Large Granular Lymphocyte Leukemia. Available online: https:/ / pubmed.ncbi.nlm.nih.gov/24014875/ (accessed on 8 July 2020).

161. Fiore, M.; Chaldakov, G.N.; Aloe, L. Nerve Growth Factor as a Signaling Molecule for Nerve Cells and Also for the NeuroendocrineImmune Systems. Rev. Neurosci. 2009, 20, 133-145. [CrossRef] [PubMed]

162. Galazios, G.; Papazoglou, D.; Tsikouras, P.; Kolios, G. Vascular Endothelial Growth Factor Gene Polymorphisms and Pregnancy. J. Matern. Fetal. Neonatal. Med. 2009, 22, 371-378. [CrossRef]

163. Gauthier, S.F.; Pouliot, Y.; Maubois, J.-L. Growth Factors from Bovine Milk and Colostrum: Composition, Extraction and Biological Activities. Lait 2006, 86, 99-125. [CrossRef]

164. Mehra, R.; Marnila, P.; Korhonen, H. Milk Immunoglobulins for Health Promotion. Int. Dairy J. 2006, 16, $1262-1271$. [CrossRef] [PubMed]

165. Struff, W.; Sprotte, G. Bovine Colostrum as a Biologic in Clinical Medicine: A Review-Part II: Clinical Studies. Int. J. Clin. Pharmacol. Ther. 2008, 46, 211-225. [CrossRef]

166. Triantafillidis, J.K.; Merikas, E.; Georgopoulos, F. Current and Emerging Drugs for the Treatment of Inflammatory Bowel Disease. Drug Des. Dev. Ther. 2011, 5, 185-210. [CrossRef]

167. Song, Y.; Pimentel, C.; Walters, K.; Boller, L.; Ghiasvand, S.; Liu, J.; Staley, K.J.; Berdichevsky, Y. Neuroprotective Levels of IGF-1 Exacerbate Epileptogenesis after Brain Injury. Sci. Rep. 2016, 6. [CrossRef]

168. Playford, R.J.; Macdonald, C.E.; Johnson, W.S. Colostrum and Milk-Derived Peptide Growth Factors for the Treatment of Gastrointestinal Disorders. Am. J. Clin. Nutr. 2000, 72, 5-14. [CrossRef]

169. Bhora, F.Y.; Dunkin, B.J.; Batzri, S.; Aly, H.M.; Bass, B.L.; Sidawy, A.N.; Harmon, J.W. Effect of Growth Factors on Cell Proliferation and Epithelialization in Human Skin. J. Surg. Res. 1995, 59, 236-244. [CrossRef]

170. Mueller, E.A.; Trapp, S.; Frentzel, A.; Kirch, W.; Brantl, V. Efficacy and Tolerability of Oral Lactoferrin Supplementation in Mild to Moderate Acne Vulgaris: An Exploratory Study. Curr. Med. Res. Opin. 2011, 27, 793-797. [CrossRef] [PubMed]

171. Poulin, Y.; Pouliot, Y.; Lamiot, E.; Aattouri, N.; Gauthier, S. Safety and Efficacy of a Milk-Derived Extract in the Treatment of Plaque Psoriasis:An Open-Label Study. J. Cutan. Med. Surg. 2006, 9, 271-275. [CrossRef] [PubMed]

172. Murata, M.; Satoh, T.; Wakabayashi, H.; Yamauchi, K.; Abe, F.; Nomura, Y. Oral Administration of Bovine Lactoferrin Attenuates Ultraviolet B-Induced Skin Photodamage in Hairless Mice. J. Dairy Sci. 2014, 97, 651-658. [CrossRef]

173. Chan, H.; Chan, G.; Santos, J.; Dee, K.; Co, J.K. A Randomized, Double-Blind, Placebo-Controlled Trial to Determine the Efficacy and Safety of Lactoferrin with Vitamin E and Zinc as an Oral Therapy for Mild to Moderate Acne Vulgaris. Int. J. Dermatol. 2017, 56, 686-690. [CrossRef]

174. Pukacka, M.; Pukacki, P.; Żaba, R.; Adamski, Z.; Mrozewicz, B. Use of Bovine Colostrum in Dermatology in the Department of Dermatology and Venerology of Poznan. Dermatol. Prakt. 2015, 7, 61-64.

175. Cosentino, C.; Elshafie, H.S.; Labella, C.; D'Adamo, C.; Pecora, G.; Musto, M.; Paolino, R.; Camele, I.; Freschi, P. Study on the Protective Effect of an Innovative Cow Milk-Based Product against Some Human Skin-Bacterial Pathogens. J. Biol. Res. 2018, 91. [CrossRef]

176. Kocic, H.; Stankovic, M.; Tirant, M.; Lotti, T.; Arsic, I. Favorable Effect of Creams with Skimmed Donkey Milk Encapsulated in Nanoliposomes on Skin Physiology. Dermatol. Ther. 2020, 33, e13511. [CrossRef] 
177. Gobbi, R.M. Pharmaceutical and Dermocosmetic Compositions Containing Equine Colostrum. U.S. Patent No. 5750149,12 May 1998.

178. Kwak, T.; Kim, K.I.; Kim, J.H.; Jung, M.G.; An, Y.; Park, S.J. Composition for Improving Atopic Skin of Fermented Product of Colostrum. KR Patent No. 20200034217A, 31 March 2020.

179. Kwak, T.; Kim, K.; Kim, J.H.; Jung, M.G.; Seo, S.A.; Seo, H.R. A Cosmetic Composition of Fermented Colostrum Product for Anti-Acne. KR Patent No. 20190060556A, 3 June 2019.

180. Gobbi, R.M. Cosmetic Compositions Containing Hyaluronic Acid and Colostrum. WO Patent 2007009790A1, 25 January 2007.

181. Park, S.M.; Lee, Y. HWhitening Functional Cosmetics Using Colostrum and Arbutin and Preparation Method Thereof. KR Patent 100619289B1, 12 April 2007.

182. Torre, C.; Jeusette, I.; Serra, M.; Brazis, P.; Puigdemont, A. Bovine Colostrum Increases Proliferation of Canine Skin Fibroblasts. J. Nutr. 2006, 136, 2058S-2060S. [CrossRef] [PubMed]

183. Zava, S.; Barello, C.; Pessione, A.; Garoffo, L.P.; Fattori, P.; Montorfano, G.; Conti, A.; Giunta, C.; Pessione, E.; Berra, B.; et al. Mare's Colostrum Globules Stimulate Fibroblast Growth in Vitro: A Biochemical Study. J. Med. Food 2009, 12, 836-845. [CrossRef] [PubMed]

184. Amiot, J.; Germain, L.; Turgeon, S.; Lemay, M.; Ory-Salam, C.; Auger, F.A. Peptides from Milk Protein Hydrolysates to Improve the Growth of Human Keratinocytes in Culture. Int. Dairy J. 2004, 14, 619-626. [CrossRef]

185. Kocic, H.; Langerholc, T.; Kostic, M.; Stojanovic, S.; Najman, S.; Krstic, M.; Nesic, I.; Godic, A.; Wollina, U. The Regenerative Potential of Donkey and Human Milk on the Redox-Sensitive and Proliferative Signaling Pathways of Skin Fibroblasts. Oxidative Med. Cell. Longev. 2020, 2020, 1-8. [CrossRef] [PubMed]

186. Kovacs, D.; Maresca, V.; Flori, E.; Mastrofrancesco, A.; Picardo, M.; Cardinali, G. Bovine Colostrum Induces the Differentiation of Human Primary Keratinocytes. FASEB J. 2020. [CrossRef] [PubMed]

187. Hewitt, E.; Mros, S.; McConnell, M.; Cabral, J.D.; Ali, A. Melt-Electrowriting with Novel Milk Protein/PCL Biomaterials for Skin Regeneration. Biomed. Mater. 2019, 14. [CrossRef] [PubMed]

188. Javanmardi, S.; Safari, I.; Aghaz, F.; Khazaei, M. Wound Healing Activities of Gundelia Tournefortii L Extract and Milk-Cream Ointment on Second-Degree Burns of Rat Skin. Int. J. Low. Extrem. Wounds 2020, 1534734620921589. [CrossRef] [PubMed]

189. Kocić, H.D.; Arsić, I.; Šmelcerović, A.; Knežević, D.; Godić, A.D. Process for Producing Cream and Serum with Partly Skimmed Donkey's Milk and L-Arginine Encapsulated in Phospholipid Nanospheres. RS Patent 20160289A1, 31 December 2018. 